\title{
Incentives and Obstacles Influencing Faculty Members' Use of Information and Communication Technology (ICT)
}

\author{
Muhannad Anwar Al-Shboul ${ }^{1}$ \\ ${ }^{1}$ Department of Curriculum and Instruction, School of Educational Sciences, The University of Jordan, Amman, \\ Jordan \\ Correspondence: Muhannad Al-Shboul, School of Educational Sciences, The University of Jordan, Amman, \\ Jordan. E-mail: malshboul@ju.edu.jo
}

Received: December 15, 2018 Accepted: January 31, 2019 Online Published: February 25, 2019

doi:10.5539/mas.v13n3p66 URL:https://doi.org/10.5539/mas.v13n3p66

\begin{abstract}
The use of Information and Communication Technology (ICT) in the classroom is very important for providing opportunities for students and learners to learn to operate in an information era. Studying the incentives and obstacles to the use of ICT in education may assist instructors to overcome these barriers and become successful technology adopters in the future. Thus, this paper investigates the factors related to the incentives and obstacles that influence the use of ICT in the educational practices as perceived by faculty members in Jordanian universities. Moreover, this article identifies factors that may affect faculty member' decisions to use ICT in the classroom. These factors are interrelated; the success of the implementation of ICT in teaching and learning process is not dependent on the availability or absence of one individual factor, but is determined through a dynamic process involving a set of interrelated factors. A web-based questionnaire was employed and distributed to all faculty members of four selected universities in Jordan for the Fall Semester 2017/2018. A total of 262 participants from a wide variety of schools have responded and completed the survey. The results of the analysis revealed that the major factors that prevent or affect faculty member' use of ICT in higher education institutions in Jordan are lack of faculty member ICT skills; lack of faculty member confidence; lack of pedagogical faculty member training; lack of suitable educational software; limited access to ICT tools; rigid structure of traditional education systems; restrictive curricula, etc. The article concluded that knowing the extent to which these factors and obstacles affect individuals and institution may help in taking a decision on how to tackle them.
\end{abstract}

Keywords: incentives and obstacles, faculty members, ICT, educational technology, higher education, Jordan

\section{Introduction}

The field of education has been affected by ICT, which have undoubtedly affected teaching, learning, and research; ICT has the potential to innovate, accelerate, enrich, and deepen skills, to motivate and engage students, to help relate school experience to work practices, create economic viability for tomorrow's workers, as well as strengthening teaching and helping schools change (Yusuf, 2005).

One of the goals for integrating ICT in education is to enhance teaching and learning practices thereby improving quality of education (Higgins, 2003). However, it has been shown that even in cases where the infrastructure is available, few educators are effectively integrating ICT in curriculum delivery (Becta, 2003). It can be said, therefore, that there are also non-technical factors that affect the adoption of ICT for curriculum delivery (Chigona \& Chigona, 2010).

ICT has been developing rapidly in recent years and opens new horizons in the field of education. There have been many significant developments in ICT-based teaching techniques and materials. Governments have been spending a significant amount of resources on ICT equipment for schools and universities. However, studies (Mishra \& Koehler, 2006; Sanchez \& Salinas, 2008; Qablan, Abuloum, \& Abu Al-Ruz, 2009) show that in both developed and developing countries, serious difficulties are being experienced during the integration of ICT-based techniques and approaches in education.

According to Yalin, Karadeniz, and Sahin (2007), researchers (Pelgrum, 2001; Hew \& Brush, 2007) identified many barriers affecting ICT integration process, which prevent teachers and instructors from deciding to use ICT in the classroom. These studies determined the factors affecting ICT integration into teaching-learning process as 
for teachers, school, and system level these factors are lack of ICT skills, low motivation for using new technologies and lack of confidence and inappropriate teacher-training constitute a barrier as for teachers to teaching-learning processes of ICT. As for the school, these barriers are lack of ICT infrastructure, poor quality and inadequate maintenance of hardware, limited access to ICT equipment, lack of appropriate training software. At the same time, lack of project experiences, which are required for systematic planning and absence of viewpoint, concerning ICT mainstreaming into schools strategies, are important barriers as for schools. At last, in the indicated studies above, it has been stated that rigid structure of traditional educational systems, traditional assessments, restrictive curricula and restricted organizational structure constitute barrier at the level of system to integration of ICT into education.

Hew and Brush (2007) determined 123 barriers as a result of meta-analysis study of 48 studies, which examined the barriers faced during technology integration into teaching-learning at K-12 level. They categorized these barriers as resources, knowledge and skills, institution, attitudes and beliefs, assessment and subject culture. They have found that ICT integration is directly affected by attitudes and beliefs of teachers, lack of knowledge and skills in the field of technology, lack of technology supported pedagogy, lack of technology- related classroom management, lack of leadership skills and lack of time-tabling structure and technology integration plan, which will enable institution to develop a common vision, lack of such resources as technology, access to technology, time and technical support.

Moreover, a number of studies (Mumtaz 2000; Becta 2003; Grainger \& Tolhurst, 2005) have shown that there are a wide range of factors which influence instructors' under-utilization of ICT in their teaching. These include access to resources, quality of software and hardware, ease of use, incentives to change, support and collegiality in their university, university policies, commitment to professional learning and background in formal ICT training. In addition, computer-phobia is argued to be a major deterrent to the utilization of ICT by instructors. It is believed that capabilities and constraints determine the efficacy (real and perceived) of an individual's taking particular actions (Nikolopoulou \& Gialamas, 2016). For many instructors who may have the capability to use ICT, lack of self-confidence in using the technology is noted to be a strong limiting factor to its use (Pelgrum, 2001; Becta 2003).

Sabaliauskas and Pukelis (2004) have discussed the barriers to successful integration of ICT into the teaching and learning process, these factors are lack of support for the educational personnel and learners, lack of teacher competencies to use certain software, insufficient financing (of teacher professional developments in ICT field, of appropriate computer hardware and software etc.), lack of cooperation among academic personnel in the same and in another schools, lack of competencies, limited accessibility, lack of support, lack of competencies, shortage of time, and change process (entry, adoption, adaptation, appropriation, and invention).

Bingimlas (2009) identified the barriers to the successful integration of ICT in teaching and learning environments, the major barriers were lack of confidence, lack of competence, and lack of access to resources. Prasad, Lalitha, and Srikar (2015) investigated the teachers' perceptions of barriers to using ICT in secondary schools in India. They have reported a number of barriers/obstacles teachers experience in using ICT in their classrooms; these include lack of resource access, inadequate training opportunities, lack of confidence amongst among teachers, paucity of time, insufficient knowledge about integration of ICT in lessons, technical issues, poor administrative support and poor fit with the curriculum.

Alkhawaldeh (2010) identified fifteen barriers to utilizing ICT for teaching and learning in Jordan as seen by the different involved stakeholders: students, teachers, and administrators; twelve of them can be directly attributed to utilization factors which were also viewed as barrier factors (expected consequences and affect toward use, habit, social norms, and facilitating condition); significant number of identified barriers can be related to "facilitating conditions" which puts more responsibility on the Ministry of Education to offer more resources and opportunities to facilitate the process of integrating technology into education in Jordan.

The tendency toward using ICT in education has entailed more pressure on the Government of Jordan to increase its effort to achieve this mission. Although these efforts have started a bit late but they resulted in the launching of the Jordan Education Initiative (JEI). This initiative started in 2003 as a public/private partnership involving the government of Jordan, NGOs, as well as local and international companies (like Cisco System) under the auspices of the World Economic Forum's Global Education (GEI). According a UNESCO report (2009), the programme trained over 3,000 Jordanian teachers in ICT skills using six e-curricula as tools to enrich the national curriculum. The programme disseminates best practices among teachers and encourages the creation of communities of practice.

On the one hand, information technology recently has been viewed as a solution to universities' cost and quality 
problems. Information technology in teaching and learning has created a need to transform how university students learn by using more modern, efficient, and effective alternative such as e-Learning (Al-Shboul, 2017). On the other hand, the acceptance and use of ICT by instructors and learners plays an essential and important role in higher education institutions. Worldwide, especially in developed countries, most students and learners are able to use ICT in their learning activities; but this is not the same among faculty members and instructors. Numerous universities in developing countries are greatly concerned about ICT use and acceptance among instructors (AlShboul, 2013).

The use of ICT in education lends itself to more student-centered learning settings. But with the world moving rapidly into digital media and information, the role of ICT in education is becoming more and more important and this importance will continue to grow and develop in the $21^{\text {st }}$ century (Noor-Ul-Amin, 2013). According to Daniels (2002), ICT has become within a very short time, one of the basic building blocks of modern society; many countries now regard understanding ICT and mastering the basic skills and concepts of ICT as part of the core of education, alongside reading, writing and numeracy.

ICT facilities and services are provided in developing countries' universities in order to enable learners to efficiently use Web-based resources and have the ability to utilize various applications of the Internet within their classroom instruction (Osman, 2014). Thus, there is a need to investigate the issue of acceptance and use of ICT, and examine factors that influence and predict acceptance and use of ICT among faculty members and instructors at higher education institutions.

Higher education institutions in Jordan have been equipped with different kind of technologies; also they conducted several training workshops for faculty members to enhance their ICT skills, so the technology to be used and integrated in the curriculum delivery in Jordanian universities. However, regardless of the availability of equipments and technology tools and applications in higher education sector in Jordan, evidence from research show that there is low adoption rate of ICT among instructors in Jordanian universities. Therefore, this interpretive study performed to analyze the factors which are encouraging or preventing faculty members from using the ICT in their teaching and learning.

The study makes a practical contribution in that it seeks to contribute towards improving the utilization of ICT for curriculum delivery in the institutions of higher education in developing countries in general and in Jordan in particular. Even though the study involved collecting the dataset from four Jordanian universities, it is hoped that the findings will be relevant to other similar universities in Jordan as well as in other developing countries.

This paper is organized as follows: Section 2 provides a literature review of the major factors affecting faculty members' use of ICT. Section 3 introduces the problem of the study, describes the purpose of the study, and lists research questions. Section 4 describes the research methodology that was used in the study, including a description of the subjects, research design, and data analysis. Section 5 presents the results and findings of the study, Section 6 provides a discussion related to the incentives and obstacles associated with the utilization of ICT at the Jordanian universities as perceived by faculty members, and Section 7 provides the conclusion, implications, recommendations, and suggestions for future research.

\section{Literature Review}

ICT has been a vital part of education in many countries including some developing countries. Some general forms ICT use includes lesson preparation; researching information on various topics; printing documents; gathering ideas from colleagues, counselors and trainers; word processing; preparing multimedia presentations (White, 2008) For the last decade, the Internet has opened a vista of opportunities to source important information and to keep instructors up to date about the latest advancement in knowledge; also instructors can open online learning forums and use blogs as part of their teaching practices (Williams, 2015).

Various opportunities may open up due to the knowledge of computers. Students can benefit by using computers and the Internet in different ways like, word processing; drawing charts; preparing presentations; solving complex mathematical problems; accessing educational websites; gathering information about any subject. With time, both the instructors and the students attain dynamic capabilities such as, updating software packages and the use of advanced features (Kozma, 2008).

In spite of growing amount of ICT tools provided to the instructors to use in their classrooms and teaching, respectively, instructors' ICT utilization is not still as predicted; research shows many barriers influencing instructors' utilization of ICT. Moreover, many researchers have identified a number of factors to describe why instructors do or do not feel ready to use ICT in their classroom instruction; they also investigated the key obstacles that prevent instructors to utilize ICT in teaching and learning process. 
The literature showed that the key factors affecting the utilization of ICT in education are lack of enough training, lack of suitable software and hardware, lack of knowledge and skills, lack of ICT leadership support, lack of time, and lack of self-efficacy. Therefore, understanding the amount to which these obstacles affect ICT users and institutes can support decision-making on how to equip them (Al-Shboul, Rababah, Al-Saideh, Betawi, \& Jabbar, 2013).

Cox, Preston, and Cox (1999) investigated the factors that support or prevent teachers from using ICT in their Classrooms. The most important factors contributing to using ICT in the classroom were school policies on using ICT, perceived ease of use, and perceived usefulness.

Rockwell, Schauer, Fritz, and Marx (1999) explored incentives and obstacles influencing higher education faculty and administrators to teach via distance using ICT tools. They examined incentives that encourage faculty to develop educational opportunities via distance using ICT and obstacles that discourage them from doing so. The primary incentives centered on intrinsic or personal rewards. These rewards included opportunities to provide innovative instruction and apply new teaching techniques as well as self-gratification, fulfilling a personal desire to teach, recognition of their work, and peer recognition. Other incentives included extending educational opportunities beyond the traditional institutional walls so place-bound students have access and release time for faculty preparation. The major perceived obstacles related to time requirements, developing effective technology skills, and assistance and support needs. Monetary awards for faculty and the cost to the student were seen as neither incentives nor obstacles.

Mumtaz (2000) reviewed the literature regarding the factors influencing teachers' decisions to use ICT in the classroom, she reported the following factors: access to resources, quality of software and hardware, ease of use, incentives to change, support and collegiality in their school, school and national polices, commitment to professional learning, background in formal computer training, lack of teaching experience with ICT, lack of onsite support for teachers using technology, lack of help supervising students when using computers, lack of ICT specialist teachers to teach students computer skills, lack of computer availability, lack of time required to successfully integrate technology into the curriculum, lack of financial support, resistance to organizational change, resistance to outside intervention, time management problems, lack of support from the administration, teachers' perceptions, and personal and psychological factors.

Pelgrum (2001) reviewed the obstacles to the integration of ICT in education as perceived by educational practitioners. He provides a list of obstacles sorted by average percentage respondents across countries where the study was conducted. These obstacles were insufficient number of computers, teachers lack knowledge/skills, difficult to integrate ICT in instruction, scheduling computer lab time, insufficient peripherals, not enough copies of software, insufficient teacher time, not enough simultaneous access, not enough supervision staff, lack of technical assistance, outdated local school network, not enough training opportunities, no time teaching explores, no time school schedule, lack information about software, not enough connections, insufficient technical support, not enough space to locate ICT tools, weak infrastructure, quality teacher training too low, software not adaptable enough, students know more than teachers, slow network performance, lack of interest of teachers, difficult use low achieving studies, telecommunications infrastructure weak, difficult finding information about how to use ICT, information overload, software curriculum incompatible, lack administrative assistance, software not in language instruction, lack support school board, no plan prevent theft/vandalism, software culturally incompatible, software too complicated to use, poor quality of the materials on the world wide web, world wide web is complicated to connect, and world wide web mail baskets overload.

Becta (2003) identified the barriers to the use of ICT in teaching. According to this study, the barriers identified in the literature can be broadly grouped into two levels: those relating to the individual (teacher-level barriers) and those relating to the institution (school-level barriers). Teacher-level barriers are lack of time, lack of selfconfidence in using ICT, negative experiences with ICT in the past, fear of embarrassment in front of pupils and colleagues, loss of status and an effective degrading of professional skills, classroom management difficulties when using ICT, lack of the knowledge necessary to enable teachers to resolve technical problems when they occur, lack of personal change management skills, perception that technology does not enhance learning, lack of motivation to change long-standing pedagogical practices, and perception of computers as complicated and difficult to use. While school-level barriers are lack of ICT equipment and the cost of acquiring, using, and maintaining ICT resources; lack of access to ICT equipment due to organizational factors such as the deployment of computers in ICT suites rather than classrooms; obsolescence of software and hardware; unreliability of equipment; lack of technical support; lack of administrative support; lack of institutional support through leadership, planning, and the involvement of teachers as well as managers in implementing change; lack of training differentiated according to teachers' existing ICT skill levels; and lack of training focusing on integrating 
technology in the classroom rather than simply teaching basic skills.

Numerous researchers have classified obstacles to the integration of ICT in education into two categories: the external and internal obstacles. The external obstacles include: lack of operational education and technological difficulties, technical problem, lack of enough time, inadequate technical support, and incomplete resources or lack of contact to quality multiplying resources. Internal obstacles relate to the educators' approaches to use ICT such as resistance to change, lack of self-confidence, instructors' negative attitudes, and lack of awareness about advantage of using ICT (Elshaikhi, 2015). However, Mirzajani, Mahmud, Ayub, and Luan (2015) reviewed the obstacles to the use of ICT in higher education institutions; as well as organized the barriers into several categories that include: (a) resource-related obstacles (b) institutional obstacles, and (c) attitudinal obstacles.

Mellar, Kambouri, Logan, Betts, Nance, and Moriarty (2007) studied the factors affecting learning-teaching events; these factors were participants' beliefs, participants' intentions, participants' resources, learning and teaching resources, the political/institutional context, and socio-cultural factors and issues of inequality. Law, Lee, Chan, and Yuen (2008) examined the factors influencing the impact of ICT use on students' learning. They found that most important factor which influencing the impact of ICT use is the professional development of the instructors.

Abbad, Morris, and de Nahlik (2009) investigated some of the major factors affecting the adoption of ICT and eLearning system in a university in Jordan. According to their study, eight factors were identified as follows: perceived usefulness, perceived ease of use, intention to use, subjective norms, Internet experiences, ICT tools and e-Learning system interactivity, self-efficacy, and technical support. Qablan, Abuloum, and Abu Al-Ruz (2009) investigated how ICT is being used in the classroom by students and teachers in Jordanian schools. They also determined socio-cultural issues influencing the use of ICT tools in public schools in Jordan.

Saleh and Burgess (2009) investigated the factors impacting the adoption and use of ICT in the Malaysian SME sector. Despite the current Malaysian government effort in regard to ICT incentives and grants, results reveal that the major hindrance for using ICT among Malaysian SME businesses include finance, employee education including ICT skills, high cost of ICT infrastructure and shortage of skilled human capital.

Keiyoro (2010) investigated the factors that influence the effective use of ICT in teaching and learning science curriculum in Kenyan secondary schools. These factors were lack of adequate training program, lack of basic technical ICT skills, lack of time allocated for the teachers to apply and implement the ICT tools in their teaching practices, lack of pertinent information and skills necessary to enable teachers to access relevant scientific information from the Internet, poor Internet connectivity, lack of the required multimedia equipment, high cost of purchasing ICT equipments and tools, lack of technical and pedagogical ICT-competence, the availability of computer laboratories, access to Internet services, and shortage of power supply.

Karimi (2012) explored the factors affecting the use of ICT in teaching and learning in secondary schools in Kenya. The finding of his study revealed that inadequate ICT infrastructure, limited ICT skills and training, limited access to technical support, lack of ICT policies in school, and budget constraints hinder the integration of ICT in teaching and learning in secondary schools in Kenya.

Player-Koro (2012) investigated teachers' attitudes to and beliefs about using ICT in education and proposed a model of how different variables are related to teachers' use of ICT in classrooms. The model suggests that positive attitudes related specifically to ICT as a useful tool for teaching and learning and a strong sense of self-efficacy in using computers in education seem to influence the use of ICT the most. Hence, according to Player-Koro's study, self-efficacy and attitudes are suggested to be mutually related to ICT use.

Tedla (2012) provided a particular focus to understand the importance, impacts, and barriers of ICT into classroom instruction in primary and secondary schools in East African Countries. The study explored internal and external factors that surround ICT issues, policies of ICT integration and factors that facilitate or impede the use of ICT, with the focus of improving the quality of teaching-learning process. The study reveals that the inhibiting factors are unrealistic policies of ICT, poor infrastructure, lack of teacher competence, confidence, incentive, perception and beliefs, imposed curriculum, lack of proper network, political instability, brain drain, sporadic electricity, poor transportation, lack of public awareness and participation, poor school leadership, technological illiteracy, and lack of pedagogical skills. The study further revealed that ICT integration is far behind in East African Schools as a consequence of ICT deficiency, absence of pre-service and in-service teacher training, and poor teachers' welfare and morale. Eventually, the study concluded that ICT is crucial for anytime and anyplace learning to ensure economic growth and it highlighted the important issues for consideration and improvements.

Al-Obisat, Alrawashdeh, Altarawneh, and Altarawneh (2013) examined the factors affecting the adoption of ICT and e-Learning in Jordanian public universities. Njuguna (2013) examined the factors that influence the use of ICT 
and e-Learning in public universities in Kenya. These factors were perceived usefulness, perceived ease of use, and supporting infrastructure. Aljaraideh and Shdooh (2014) explored the factors effecting the extent to which ICT is used by the teaching members at Jerash University in Jordan. Zureikat (2014) identified the effect of using ICT in the educational process in the Jordanian universities.

Alshmrany and Wilkinson (2014) examined the current integration of ICT in Saudi Arabian secondary schools; they also analyzed the various barriers impeding the incorporation of ICT in the educational system; furthermore, they developed several strategies of promoting the ICT usage. Mulhim (2014) reviewed a number of factors that hinder teachers' use of ICT in their teaching in the context of Saudi Arabia; she summarized the barriers to the use of ICT in teaching in Saudi Arabia as follows: lack of access to ICT, lack of training, and lack of time.

Osman (2014) investigated the issue of acceptance and use of ICT, and examined factors that influence and predict acceptance and use of ICT among staff members of Khartoum State Universities in Sudan. He reported that the motivating factors (incentives) and reasons of ICT use were accessing fast and updated information; developing, improving and participating in professional development; fond of using ICT; fun and enjoyment in ICT use; for pleasure and delight; originally it is a personal issue; satisfaction and excitement in using ICT; correspondence of personal values and institution's values; due to the institution's values and rules; because colleagues use it; because it is connected with monetary incentives; the necessity of using because of monetary incentives; and because of extra payment, need to exert efforts to use ICT. The study also revealed that the main problems that usually hinder or inhibit the use of ICT were low speed of the connection; Internet access problem; accessing specialized online database; technical problem; lack of university support and incentives; lack of sufficient ICT training; not enough time (work pressure); misuse of Internet; unclear property, copy, and publishing rights; high cost for using the Internet; instability of electricity or frequent disconnections; social bindings prevent from using it efficiently in work; unavailability of suitable information in Arabic language; personal use (newspapers, following news, etc.) affects the academic uses; English language is an obstacle for using the Internet; using it not compatible with the instructor's subject (profession); fear of using computer and Internet in lectures; and using it contradicts with social, religious, and cultural beliefs.

Agbo (2015) studied the factors influencing the use of ICT in teaching and learning computer studies in Nigeria; these factors are teachers' characteristics, school support, availability of vision and plan about the contribution of ICT to education, level of and accessibility to the ICT infrastructure, availability of time (to experiment, reflect, and interact), available support to computer-using teacher in the workplace, school culture, computer attributes, level and quality of training for teachers and school principals, attitude towards computer, computer competence, and effective training program.

Albugami and Ahmed (2015) examined the success factors for ICT implementation in Saudi secondary schools. The results of their study showed that ICT was perceived as an important tool in improving performance, collaboration, learning experience and learning outcomes. However, some challenges that affect the application of ICT in Saudi schools are lack of ICT resources, lack of ICT maintenance, lack of ICT skills, lack of teachers ICT training, lack of clear ICT policies, lack of management and technical support, time limitations, lack of teachers confidence, lack of teachers pedagogical training, teacher attitudes and beliefs towards ICT, resistance to change, and lack of progressive evaluation. However, the overcoming of these obstacles could turn these barriers into positive factors to aid in the success of ICT implementation.

Alenezi (2015) determining technical, political, and cultural implementation factors that influencing ICT adoption in Saudi Arabia secondary schools. Technical implementation factors were shortages of ICT tools available in the school, lack of ICT tools in the classroom, and dependence of teachers on the technical service of ICT tools. Political implementation factors were mandatory uses of ICT in schools as prescribed by the educational authorities, and teachers are left by themselves with little administrative support and no culture of collaborating in sharing ICT experience. Cultural implementation factors were the culture of ICT implementation needs developing, the presence of ICT in schools directs teachers towards personal growth, teachers need to know how appropriate ICT tools can be used in a changing learning and teaching environment, and ICT-competent Saudi teacher realizes the appropriateness of ICT tools used.

Aljaberi (2015) determined the competencies and technological roles of teachers who are able to employ technology in education and keep themselves up-to-date with the requirements of the era of ICT. She discussed topics related to ICT skills teachers already have and gaps in knowledge, teachers' current use of technology in the classroom and factors that influence this use, teachers' prior ICT training experiences, and teachers' ICT training preferences.

Alzubi and Omar (2015) studied the factors influencing the effectiveness of ICT and EduWave e-Learning platform 
in the educational process in Jordan. The results of their study showed that there is an impact of the ICT and eLearning system (training the users, infrastructures, the ability of the system to meet the needs of users, the powers granted for the users (authority), perceived usefulness, and perceived ease of use) combined on the effectiveness of the system.

Khasawneh (2015) studied the factors influence ICT and e-Learning utilization in Jordanian Universities as perceived by academic staff. The findings of his study show that self-efficacy and facilitating condition have positively affected the behavioral intention to use ICT in the higher educational system among academic staff in Jordan. The study also revealed that there is a significant relationship between academic staff's perception of technology characteristics and their perceived behavioral control towards using the technology in the educational system.

Ghavifekr, Kunjappan, Ramasamy, and Anthony (2016) examined the issues and challenges associated with the use of ICT tools in teaching and learning as perceived by Malaysian teachers. They analyzed teachers' perceptions of the challenges faced in using ICT tools in classrooms. Overall, the key issues and challenges found to be significant in using ICT tools by teachers were: limited accessibility and network connection, limited technical support, lack of effective training, limited time, and lack of teachers' competency.

Kafyulilo, Fisser, and Voogt (2016) investigated the factors affecting teachers' continuation of technology use in teaching. The findings of their study revealed that despite the challenges that all teachers in the sample encountered when using technology in their teaching (such as large classrooms, problems with electricity supply, lack of time, and lack of technology tools), the encouragement of school management was a critical factor in teachers' continuation of technology use. Kennah (2016) examined the main factors that influence the pedagogical use of ICT in schools; these factors were teachers' pedagogic use of ICT, teacher ICT skills and competent, and access and ICT infrastructure.

Al-Mofarreh (2016) identified factors (practical or material factors) that facilitate and hinder the implementation of the ICT policy in secondary schools in Saudi Arabia. According to his study, the important factors facilitating the implementation of the ICT policy in secondary schools were the awareness of the importance of the use of technology in the classroom, the change management as instrumental to the successful implementation of the ICT policy, appropriate ICT teachers' training program, well-equipped environments to learn how to use technology in the classrooms, support from the administrative, and perceived benefits from using technology by the teachers. While the factors that may hinder ICT policy implementation in schools were lack of specialized personnel in technology, lack of computer skills in using technology, inadequate training, lack of ICT infrastructure, bureaucracy and routine in maintenance of computers, lack of financial support, inadequate/slow Internet connection, lack of motivation for the teachers to use ICT, lack of a clear mechanism to connect the performance of the teachers in technical skills with their job behaviour, lack of time, lack of technological tools, and lack of knowledge about technology and ICT policies.

Alshmrany and Wilkinson (2017) also investigated the factors influencing the adoption of ICT by teachers in primary schools in Saudi Arabia. Analysis of the data showed computer literacy and confidence with technology registered a significant positive effect on the study, participants' effort expectancy, which in turn positively influenced their behavioural intention to adopt ICT. On the other hand, Saudi culture, social conditions, system quality, and other obstacles discourage the uptake of ICT by primary school teachers. According to Alshmrany and Wilkinson, the findings of their study will assist the Saudi government to enhance the positive factors and eliminate or reduce the negative factors to ensure successful adoption of ICT in primary education by teachers in Saudi Arabia.

Ameen, Willis, and Abdullah (2017) identified the challenges facing the use of ICT and e-Learning systems in Iraqi universities from the students' perspectives. These challenges are namely infrastructure, the culture of teaching and learning, the design and support of the system, and students' readiness.

Gasaymeh, Al-hasanat, Kraishan, and Abutayeh (2017) examined motivational factors affecting the integration of ICT in the educational practices of faculty members at a university in Jordan. They found that the most significant motivational factors were internal and personal ones related to the direct benefits of ICT in terms of enhancing faculty members teaching practices, enhancing students' learning, and improving faculty members job satisfaction. External factors include physical and moral motivational factors, as well as university support and encouragement. The researchers reported that these were the major factors which influence the participants' use of ICT for educational purposes.

Aslan and Zhu (2018) investigated the factors influencing the integration of ICT of starting teachers in lower secondary schools in the Turkish context. Lawrence (2018) identified the factors that influence teachers' decision 
to integrate ICT in teaching and learning. His study aims to fill the gap by using in-depth case studies, conceptualized within the grounded theory method to develop a model that will explain and enhance the understanding of the factors influencing teachers' integration of ICT in teaching and learning.

Li, Yamaguchi, and Takada (2018) conducted a study aims to understand the factors affecting primary school teachers' perceptions on use of ICT for student-centered education in Mongolia. The study found that (a) teacher's professional competency and perception of benefits on use of ICT are significant factors affecting the use of ICT tool for student-centered education; (b) teacher cooperation is affecting teachers' perceptions on use of digital contents for student-centered education; and (c) endogenous teacher level factors such as teacher's job satisfaction and self-confidence are affecting teachers' perception on the use of ICT for student-centered education in Mongolia.

According to the reviewed literature, the major factors influencing integration of ICT and the key challenges and barriers to integrating ICT in higher education from the instructors perspectives are lack of infrastructure, lack of resources, lack of technology, lack of access to technology, lack of time, inadequate technical support, lack of knowledge and skills, lack of appropriate administrative support, user's attitudes, lack of technical support, lack of competence, lack of access to resources, resistance to change, lack of ICT equipment in classrooms, rigid structure of traditional education systems, users' beliefs and practices, lack of incentives and motivations, lack of sharing best practices, disbelieving ICT benefits, lack of confidence, lack of technical staff, low speed internet, restrictive curricula, lack of timely feedback from instructors, lack of awareness, Internet usage, language barriers, teaching workload, and lack of ICT policy (Al-Shboul, Al-Saideh, \& Al-Labadi, 2017).

In general, ICT integration into instruction is beneficial for learners' achievement and learning and, in an ideal world, would be fully assimilated into the curriculum. Unfortunately, there are often significant barriers to the successful integration of ICT in teaching and learning environments in institutions of higher education in Jordan.

In short, ICT utilization in higher education continues to be critical all around the world; low level of use of ICT into teaching and learning environment is critical issue in higher education. According to reviewed literature, it is observable that utilization of ICT in higher education is affected by numerous obstacles. A diversity of activity plans have been established to an efficient utilization of ICT in teaching and learning process, but numerous obstacles still happen in preparation. To facilitate these activities, obstacles are necessary to be recognized so that they might be solved. Hence, it is suggested that understanding the amount to which these obstacles affect ICT users and institutes can support decision-making on how to overcome and equip them.

\section{Statement of the Problem, Significance of the Study, and Questions of the Study}

\subsection{Statement of the Problem}

ICT is becoming increasingly important in our daily lives and in our educational system. There is a growing demand on educational institutions to use ICT to teach the skills and knowledge students need for the digital age (Lawrence \& Tar, 2018). The adoption and integration of ICT into teaching and learning environment provides more opportunities for teachers and students to work better in a digital globalization age. ICT has the potential to play an increasingly important role in education, specifically in classroom, administration, and online instruction or other activities (Lawrence, 2018). There is tremendous potential for teachers and students to harness the power of ICT to improve the quality of teaching and learning in the classroom.

Research on ICT diffusion in Jordanian universities stated that there is a clear gap between the availability of ICT tools in Jordanian higher education institutions and strategies/methods of implementation (Al-Zoubi, Kahhaleh, Hasan, \& Kharouf, 2007; Mofleh \& Wanous, 2008; Al-Mobaideen, 2009; Al-Khasawneh, 2012; Khasawneh \& Ibrahim, 2012; Alassaf, 2014; Alkhawaldeh \& Menchaca, 2014).

Moreover, in spite of the belief of policymakers worldwide that ICT is essential for improving the quality of life for individuals in developing countries such as Jordan, research suggests that many factors play a part in effectively integrating ICT into educational systems (Al-Mobaideen, 2009). Jordanian universities have exerted great efforts to include ICT in their educational courses. For achieving this, money was dedicated to provide the needed ICT equipment, tools, and devices. In addition, training programs have been extendedly held to educate and train lecturers how to efficiently use ICT tools and modern technologies in teaching and learning.

Bearing in mind that these new trends have begun recently in Jordan, and are an ongoing process, there is still a need for further insights into the state of educational setting with respect to the contribution of ICT in the educational field. These insights will give a clear picture about efforts dedicated and money spent on education computerizing related project and the general contribution of ICT in educational process in Jordanian universities. On this level, there are several claims from lecturers in Jordanian universities about their unwillingness to use ICT as they are a major concern for them and a threat for their careers. Many lecturers believe that ICT is a major threat 
for them and will make a key shift in the common vision of the lecturers as being the only source of knowledge, thus marginalizing their role (Alassaf, 2014).

Additionally, the use of ICT initiatives in the academic and training institutions has been increasing in last few years. ICT concept has been implemented by academic institution in Jordanian universities, and becomes a must in order to support their teaching-learning activities (Abu-Qudais, Al-Adhaileh, \& Al-Omari, 2010). There is a lack of research on the main factors contribute to success of ICT and using it in education, particularly, studying the awareness and attitude of the Jordanian academic staff towards using ICT. There are many factors that affect adoption of ICT by the faculty members related to social-cultural issues, pedagogical issues, and technologies and infrastructure issues. Consequently, there is no meaning in just investing huge amounts of money in equipping universities with ICT tools unless they are used effectively (Tezci, 2009). Furthermore, the greater availability of technological resources in the classroom does not necessarily equate to improved academic achievement (Wozney, Venkatesh, \& Abrami, 2006).

Additionally, school teachers' perspectives on the use of ICT in education have recently been examined and explored by many Jordanian researchers, whereas research studies on Jordanian faculty members' perspectives on the use of ICT in the teaching and learning process were rarely investigated. Therefore, there is a need to investigate the factors associated with ICT use as perceived by faculty members at higher education institutions within the Jordanian context. So, the main purpose of this study is to explore the challenges that face the implementation of ICT in education in public universities in Jordan. Particularly, to examine the potential prominent factors affecting the ICT usage by the academic staffs in the Jordanian universities.

Hence, how to support the implementation of ICT in higher education sector in Jordan, what incentives encourage its successful implementation, what barriers hinder its successful implementation, what the best methods to make the ICT application more effective, and what kind of support ICT stakeholders need are remain serious questions for Jordanian decision-makers and educators. Accordingly, this research sets out to explore the incentives and barriers that might promote or prevent the effective utilization of ICT in institutions of higher education in Jordan as perceived by faculty members, in order to propose a strategic approach for successful ICT implementation in Jordan at the post-secondary level.

In view of that, in this study, the researcher focuses on studying the factors related to the attitude of faculty members towards using ICT in instruction. The findings of this study will contribute to ICT adoption by Jordanian universities and help in implementing successful frameworks of embedding ICT in universities' educational system. Consequently, the primary purpose of this research is to identify the factors that affect the attitudes of faculty members towards using ICT in education in Jordanian universities.

\subsection{Significance of the Study}

This study is important research in the field of technology integration in higher education in a developing country. However, the significance of this study comes from its aim, which is to examine instructors' perceptions on the use of ICT in higher education institutions in Jordan and to explore the barriers that might prevent the effective integration of ICT in teaching and learning process in higher education from the faculty members' perspectives at Jordanian universities.

Although the success factors for ICT deployment and the factors that hinder ICT employment in higher education from the perspective of school teachers and students, in general, have been the subject of many studies over the last two decades, only a few studies, for instance, (Al-Adwan \& Smedley, 2012; Al-Adwan, Al-Adwan, \& Smedley, 2013; Almarabeh, 2014; Almarabeh, Mohammad, Yousef, \& Majdalawi, 2014; Qablan, 2015; Gasaymeh, AlJa'afreh, Al-Dmour, \& Abu-Alrub, 2016) have been conducted in order to examine and explore ICT utilization in Jordanian universities from faculty members' point of view.

Most Jordanian research studies have focused on the use of ICT on specific subjects, such as Science, Mathematics and English. In addition, the majority of these studies (in the ICT context) were of a small scope; unpublished research projects conducted to fulfill degree requirements (i.e. Master's and $\mathrm{PhD}$ degrees). Therefore, this study attempts to fill a key gap in the literature, proposing a framework to gather essential data that allows an emphasis on the areas where the hindrances mainly lie and how they can be resolved in Jordan higher education institutions. This approach means that previously unheard voices can now be considered and, subsequently, key areas can be underpinned that will clearly show where steps can be taken to make improvements at the post-secondary education level, within the Jordanian context.

However, the majority of studies related to ICT implementation in higher education have been carried out in developed countries (Shaw, 2010), while ICT in the Jordanian educational system is somewhat new. There are 
some factors affecting ICT implementation in Jordanian higher education institutions which differ from Western countries; for example: culture, economy and educational system. Therefore, further research needs to be undertaken to investigate the current situation in Jordanian universities, in order to determine the challenges that could prevent the implementation of ICT and suggest the main factors that could make the use of ICT in Jordanian universities more successful.

The results of this study could considerably benefit the Ministry of Higher Education and Scientific Research in Jordan by enhancing their awareness about the current situation in Jordanian higher education institutions and barriers that might hinder the successful utilization of ICT. In addition, the findings of this study might assist the decision makers at the Ministry of Higher Education and Scientific Research in making informed decisions regarding the training and development of instructors that will result in an increased use of ICT to gain the maximum benefit for students/learners and to support the educational process in Jordan at the undergraduate level.

Finally, the findings of the study would help the stakeholders in higher education to understand the factors that affect the use of ICT in the education system and make relevant decisions. The Ministry of Higher Education and Scientific Research would use the findings to formulate the appropriate ICT policies in line with the National ICT Policy. The university administration would use the findings in making decisions on how to improve the level of the use of ICT and how to overcome the anticipated obstacles related to ICT use. The curriculum developers would find the result of the study important in developing ICT training program that would maximize the potential use of ICT in education.

In summary, the results of this study would be useful to modify, develop, and adopt new methods of teaching, training, and preparation programs in Jordan regarding the use of ICT in learning environments at the postsecondary education level. Moreover, the results of this study provide a variety of information that can benefit the relevant decision makers by considering the barriers that might prevent the effective deployment of ICT in higher education in Jordan. Additionally, this study presents patterns of good practice as well as areas of concern and provides a series of recommendations for policy-makers and universities administrators that, if implemented, would serve to enhance the learning experience of the learners in Jordanian universities.

\subsection{Purpose of the Study}

User' attitudes and perceptions toward introducing new technology to support learning and teaching represent an important factor in predicting their adoption of this technology in the educational environment (Rogers, 2003). Users' perceptions and attitudes have been identified as key factors in the successful integration of new technology in education (Rogers, 2000). For ICT to be effectively used in higher education, its introduction into learning and teaching needs to be accompanied with assessments of instructors' perceptions and attitudes in order to provide information on how it can be implemented.

Margaryan, Littlejohn \& Vojt, (2011) recommend that to inform policy and practice regarding technology integration, higher education practitioners should examine what technologies users have access to and what their preferences are, as well as the educational value of these technologies. A limited number of studies have examined the motivational factors for ICT use among faculty members in Jordan. Policy makers and educational practitioners need to understanding faculty members' perceptions of the motivational factors affecting their use of ICT so that they know how to encourage faculty members to use ICT. Thus, the purpose of the study was to examine the motivational factors affecting faculty members' integration of ICT into their educational practice. Additionally, this study investigated and examined faculty members' perceptions of the utilization of ICT in the universities' classrooms in Jordan and the factors that may affect their usage of it. Furthermore, the purpose of this study was to determine and explore the barriers that might prevent the effective integration of ICT into Jordanian universities from the perspectives of faculty members.

In conclusion, the ultimate goal of this investigation was to identify the factors that influence the effective use of ICT tools as perceived by Jordanian faculty members. The study attempted to reveal the challenges and problems that these faculty members encountered in the process of implementing the ICT-based teaching and learning in higher education setting. Consequently, this investigation sought to identify the factors that promote and/or hinder the use of ICT in teaching and learning process from instructors' perspective.

\subsection{Questions of the Study}

The main aims and objectives of this study are (a) to identify the incentives influencing faculty members use of ICT in Jordanian higher education institutions, (b) to identify the obstacles that might prevent the effective use of ICT tools in Jordanian universities, and (c) to propose recommendations to improve ICT implementation in higher education in Jordan and overcome the anticipated barriers. Thus, based on the research purposes and objectives, 
the study aims to answer the following research questions:

1. What are the main incentives for using ICT in higher education institutions in Jordan as perceived by faculty members?

2. What are the main obstacles for using ICT in higher education institutions in Jordan as perceived by faculty members?

\section{Research Methodology}

This section of the research paper presents the methodology and research design used to explore the factors which are related to the incentives and obstacles that influence the use of ICT in the educational practices as perceived by faculty members in the Jordanian universities. The current study followed a quantitative method approach in which data were collected using a Web-based questionnaire. However, this section aims to describe the research method, study population, research instrument, data collection methods, and data analysis procedures, aiming at highlighting those used throughout the study to achieve its objectives.

\subsection{Research Method}

A quantitative research approach was used in this study; thus, the methodology used in this study employed quantitative data collection procedures. However, descriptive research was used as a methodology to answer the research questions. The majority of the survey questions took the form of an attitude scale similar to a Likert-type scale. Respondents addressed each statement using a five-point rating scale, specifically Likert-type response set: $1=$ strongly disagree, $2=$ disagree, $3=$ do not know, $4=$ agree, $5=$ strongly agree; in addition to some statements took the form of closed-ended questions, or what is called dichotomous or two-point questions, (e.g. 'Yes' or 'No', 'Satisfied' or 'Unsatisfied'); moreover, there were three open-ended questions to obtain more in-depth details and to get more thoughtful responses about the participants' perceptions regarding the factors that effect their use of ICT tools.

\subsection{Population of the Study}

The accessible population for this study was all faculty members from four Jordanian universities: The University of Jordan (UJ), Jordan University of Science and Technology (JUST), The Hashemite University (HU), and AlZaytoonah University of Jordan (ZUJ). Each university participated in the study has uploaded an electronic version of the survey on its online registration system and sent invitation letters via email to all its faculty members containing the link to the Web-based survey asking them to participate in the study. The study was conducted at the beginning of October of Fall Semester 2017/2018; a total of 262 surveys were completed and returned. Thus, the sample size $(N)$ of the study was 262 respondents from all academic disciplines from four Jordanian universities. Table 1 shows the participants' representation with regard to the university.

Table 1. Participants Representation with regard to the University ( $N=262)$

\begin{tabular}{lcc}
\hline \multicolumn{1}{c}{ University } & Response Total & Response Percent \\
\hline The University of Jordan (UJ) & 124 & $47.3 \%$ \\
Jordan University of Science and Technology (JUST) & 36 & $13.7 \%$ \\
The Hashemite University (HU) & 50 & $19.1 \%$ \\
Al-Zaytoonah University of Jordan (ZUJ) & 52 & $19.9 \%$ \\
Total & $\mathbf{2 6 2}$ & $\mathbf{1 0 0 \%}$ \\
\hline
\end{tabular}

\subsection{Data Collection Procedures}

The data were collected via a Web-based survey that was developed for exploring the instructors' perspectives of using ICT in institutions of higher education in Jordan as well as investigating the major incentives and barriers to integrating ICT into the teaching and learning process at Jordanian higher education. Since the target population for this study was consisted of faculty members from four Jordanian universities, the researcher obtained the Human Subjects Committee approval from the Institutional Review Board (IRB) of each university at the end of September 2017. A request to conduct this study was sent to the administrative offices at these universities. The survey was distributed to all faculty members at the selected universities at the beginning of October 2017; email reminder notices were sent to the participants two weeks following the initial distribution; the survey was completed at the beginning of November 2017. A total of 284 surveys were returned, and 22 incomplete surveys 
were excluded. Hence, the sample size was 262 participants from the four universities participated in this research study. In short, a web-based questionnaire was employed and distributed to all faculty members at four selected Jordanian universities for the Fall Semester 2017/2018. A total of 262 participants from a wide variety of schools and colleges, in each selected university, have responded and completed the survey.

\subsection{Limitations of the Study}

This study has encountered some limitations and constraints; so generalization of the results to other academic institutes should cautiously be done. These limitations are as follows:

- The study was conducted in Fall Semester during the academic year of 2017/2018, it only focused on higher education faculty members, and the sample was drawn from only four universities in Jordan: UJ, JUST, HU, and ZUJ.

- The study was focused only on examining the instructors' perceptions towards the use of ICT in higher education institutions in Jordan, and investigating the incentives and barriers that might motivate or prevent the effective implementation of integrating ICT tools into Jordanian higher education.

- The incentives and barriers that might motivate or prevent the effective utilization of ICT tools into Jordanian higher education were explored only from the perspective of faculty members at four universities in Jordan.

- The participants were selected to participate in this study based on those who have an access to the Internet and have official university email accounts which are available for all employed instructors.

- There was a limitation related to the selection bias, in "open" Web-based surveys, selection bias may occur due to the non-representative nature of the Internet population, and more importantly through selfselection of participants, i.e. the non-representative nature of respondents.

- Using the Internet for surveys requires an awareness of technical issues such as the user's Web browser, network connectivity, and user interface design.

- Throughout this research paper, the terms 'faculty members' and 'instructors'; as well as the terms 'obstacles' and 'barriers' are used interchangeably by the researcher.

\subsection{Research Instrument}

To collect data, the researcher used a Web-based survey that explored faculty members' perceptions on the use of ICT in higher education institutions in Jordan and examined the incentives and barriers or obstacles to utilizing ICT into Jordanian higher education. The survey was developed after reviewing several existing surveys that are related to topic of the study. The researcher created most of the survey items, and used some from the literature review after modified them to fit with the aims and scope of the current study. The majority of the items came from one source and were modified to fit the objectives of this study; this source was a study conducted in 2014 by Al-Shboul, titled "Faculty Members' Perceptions of E-Learning at The University of Jordan". Since the author of the indicated source is also the same author of this research paper, there was no need to obtain a permission request for the researcher to use some items from the Al-Shboul's survey.

After modification and development, the survey contains 23 items in total consisted of the followings: demographic information, instructors' perceptions towards ICT, and incentives and obstacles/barriers concerning the use of ICT as perceived by instructors (See Appendix). However, in most survey items, faculty members' responses were measured on a five-point Likert-type scale of $\quad(1=$ strongly disagree, $2=$ disagree, $3=$ do not know, $4=$ agree, $5=$ strongly agree); in addition to two-point questions ('Yes' or 'No').

\subsection{Validity and Reliability}

Content validity serves the assessment of whether the variables used to represent the concepts reflect accurately the content and definition of the needed concept (Bryman \& Bell, 2015). To do that, the questionnaire was administered to participants-exactly the same way it will be administered in the main study- to fill them and provide their feedback in order to improve the internal validity of the questionnaire. As a result, the total numbers of questions were 28 questions; five questions were deleted and two questions were modified. Hence the final version of the questionnaire was consisted of 23 items. The average time to fill out the faculty members' questionnaire was less than 10 minutes, which is considered reasonable.

Cronbach's alpha coefficients for the data reported in this study were as follows: $\alpha=0.85$ for instructors' perspectives towards the use of ICT dimension (subscale), $\alpha=0.89$ for the perceived incentives to ICT use subscale, and $\alpha=0.87$ for the perceived obstacles/barriers to ICT use subscale. The reliability of overall scale was also 
calculated using Cronbach's alpha coefficient, with a value of $(\alpha=0.88)$; which is considered to be an acceptable level for internal consistency reliability. Since $\alpha=0.70$ is considered an acceptable level for social science research (Bryman, 2012; Field, 2013), the internal consistency reliability for the instrument as well as for the questions related to each subscale can be considered acceptable.

In summary, the researcher calculated the Cronbach's Alphas separately for each dimension in order to measure the consistency of scores across items. As mentioned above, the values of the Cronbach's Alpha coefficients for these dimensions/subscales were high enough to indicate that there is adequate consistency among the survey items in each subscale; these values showed acceptable high levels of consistency. Overall reliability is good, reflecting that each of the subscales include items that have consistent answers with each other.

\subsection{Data Analysis Procedures}

Following data collection, descriptive statistics were used in the study; statistical analyses were performed on the data collected from the surveys. Data analysis included the use of frequencies, percentages, means, and standard deviation. Data analysis and computations for all statistical techniques were performed using the Statistical Package for Social Science (SPSS), version 20.0, to analyze the data in light of the research questions. Then, the results were reported based on the analyzed data; however, the results from the analyses assisted the researcher in reaching conclusions on the instructors' perceptions towards the utilization of ICT in higher education in Jordan, as well as on the potential incentives and obstacles/barriers that might motivate or prevent the effective use of ICT in higher education institutions in Jordan.

\section{Data Analysis and Results}

The purpose of this study was to investigate the current issues related to the ICT utilization in higher education institutions in Jordan as perceived by faculty members. Moreover, this paper identifies factors related to the incentives and obstacles that may affect instructors' use of ICT in teaching and learning processes at Jordanian higher education institutions. In addition, this article explores the major issues that might motivate or prevent the effective use of ICT in higher education in Jordan from the faculty members' perspectives. As mentioned earlier, participants were requested to respond to twenty Likert-type statements, in addition to two open-ended questions, dealing with faculty members' perceptions towards ICT integration into higher education (See Appendix); the instructors' ICT perceptions were presented by frequencies, percentages, and mean scores on five-point Likerttype response scale where five (Strongly Agree) shows the maximum score and one (Strongly Disagree) represents the minimum score; in addition to some statements took the form of two-point questions, (e.g. 'Yes' or 'No'). The findings of this study are presented in the following sections.

\subsection{Demographic Information}

The study was conducted during the Fall Semester of the academic year 2017/2018; a total of 262 surveys were completed and returned. Thus, the sample size $(N)$ of the study was 262 respondents/instructors from all academic disciplines from four Jordanian universities. Figure 1 shows the participants' representation with regard to the university.

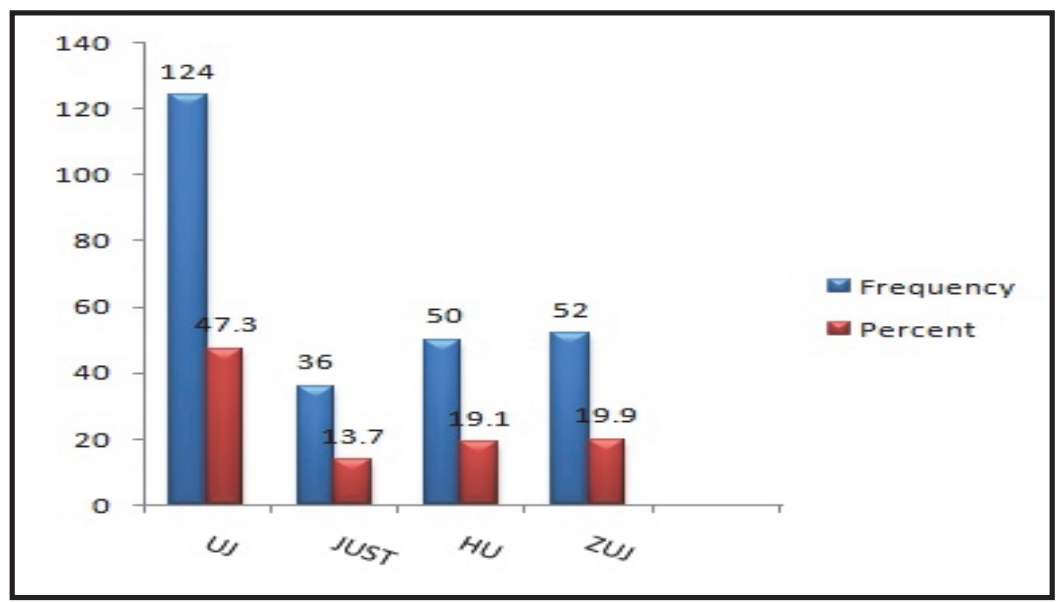

Figure 1. Distribution of the Respondents (the sample) according to the University (Frequency and Percent)

As shown in Figure 1 above, 262 respondents were completed and returned the survey from the four Jordanian universities participated in this study; 124 (47.3\%) were from the University of Jordan (UJ), $36(13.7 \%)$ were from Jordan University of Science and Technology (JUST), 50 (19.1\%) were from the Hashemite University (HU), and 
52 (19.9\%) were from Al-Zaytoonah University of Jordan (ZUJ).

The respondents' age consisted of 20 less than 30 years old (7.6\%), 90 between 30 and 45 years old (34.4\%), 105 between 45 and 60 years old ( $40 \%)$, and 47 more than 60 years old (18\%). The respondents' faculty rank consisted of 43 lecturers (16.4\%), 68 assistant professors (26.0\%), 70 associate professors (26.7\%), and 81 full professors $(30.9 \%)$, as shown in Figure 2.

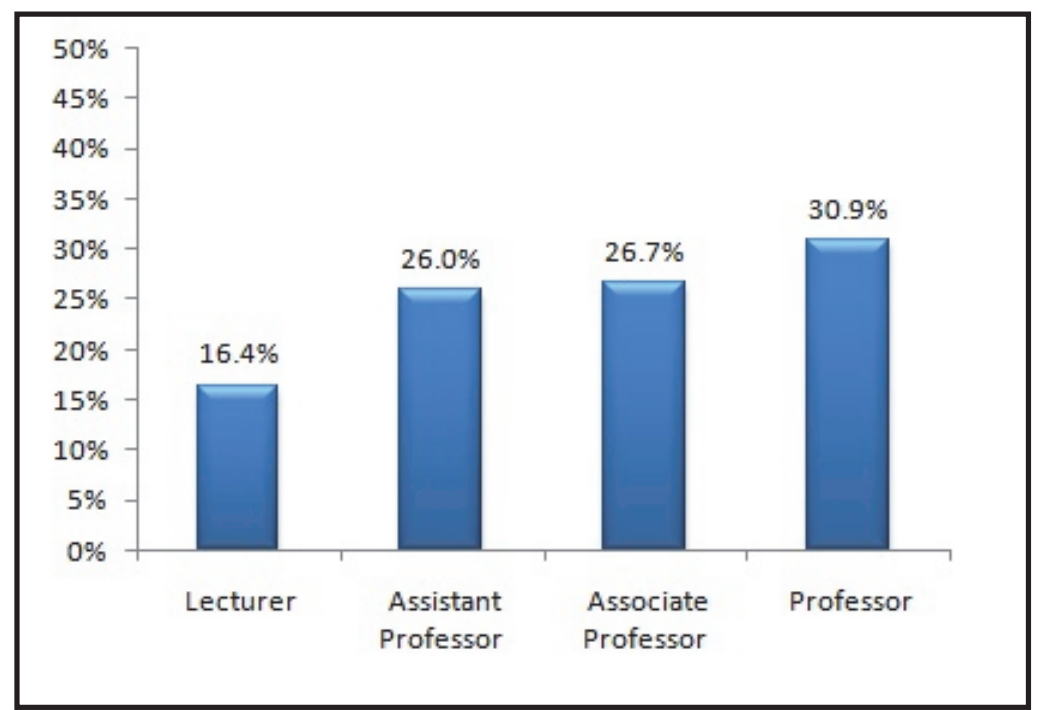

Figure 2. Distribution of the Respondents according to the Faculty Rank (Percent)

The respondents' teaching experience includes 53 who have $0-5$ years of teaching experience (20.2\%), 62 who have 6-10 years of teaching experience (23.6\%), 33 who have $11-15$ years of teaching experience $(12.6 \%), 33$ who have 16-20 years of teaching experience (12.6\%), 28 who have $21-25$ years of teaching experience (10.8\%), and 53 who have more than 26 years of teaching experience (20.2\%).

The results indicated that 144 respondents are using ICT for less than 5 years (55\%), 82 respondents are using ICT from 6 to 10 years (31.3\%), 20 respondents are using ICT from 11 to 15 years (7.6\%), 13 respondents are using ICT from 16 to 20 years (5\%), and 3 respondents is using ICT for more than 20 years $(1.1 \%)$.

The results indicated that there were 38 respondents from School of Engineering and Technology (14.5\%), 44 respondents from School of Science (16.8\%), 51 respondents from Arts and Humanities Schools (19.5\%), 53 respondents from Health Schools (20.2\%), 6 respondents from School of Business (2.3\%), and 70 respondents from other schools (26.7\%).

\subsection{General Findings}

In question about the type of ICT delivery tools faculty members are currently using or previously have used, the faculty respondents indicated that they are currently using or previously have used most is Moodle. Sixty-six faculty members indicated that they are using or have used this type of ICT as delivery tool (25.2\%). Fifty-three faculty members indicated that they are using or have used Blackboard as ICT delivery tool (20.2\%). Forty-six faculty members indicated that they are using or have used Mobile Learning (Twitter/Facebook/WhatsApp) $(17.6 \%)$. Thirty-two faculty members indicated that they are using or have used Self-created Webpage as ICT delivery tool $(12.2 \%)$. Eighteen faculty members indicated that they are using or have used WebCT as ICT delivery tool $(6.9 \%)$. Nine faculty members indicated that they are using or have used Webboard as ICT delivery tool of their classroom instructions (3.4\%). However, 38 faculty members indicated that they have used other ICT delivery tools (14.5\%). Figure 3 illustrates the type of ICT delivery tools that the respondents are currently using or previously have used most. 


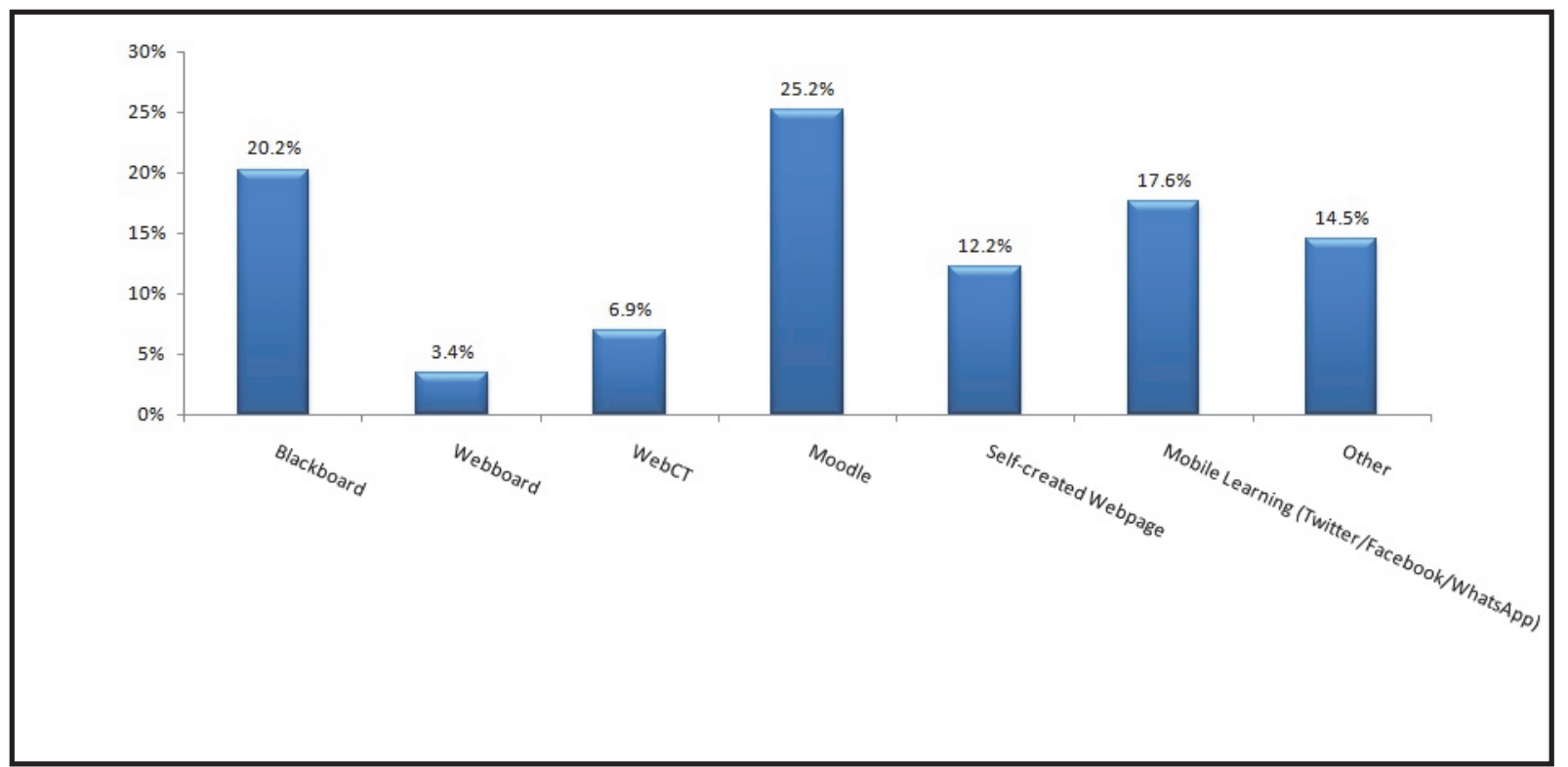

Figure 3. Type of ICT Delivery Tools Are Currently Using or Previously Have Used Most by the Respondents (Percent)

In a question about faculty members' plans regarding using ICT tools in education, 30 faculty members indicated that they have no plans to teach a course using ICT tools (11.5\%). One hundred eighteen faculty members indicated that they plan to teach a course utilizing best practices in ICT in education in the coming year (45\%). Sixty-two faculty members indicated that they have taught a course utilized best practices in ICT in education (23.7\%). Fiftytwo faculty members indicated that they currently teach a course utilizing best practices in ICT in education $(19.8 \%)$. Figure 4 represents faculty members' plans regarding using ICT tools in education.

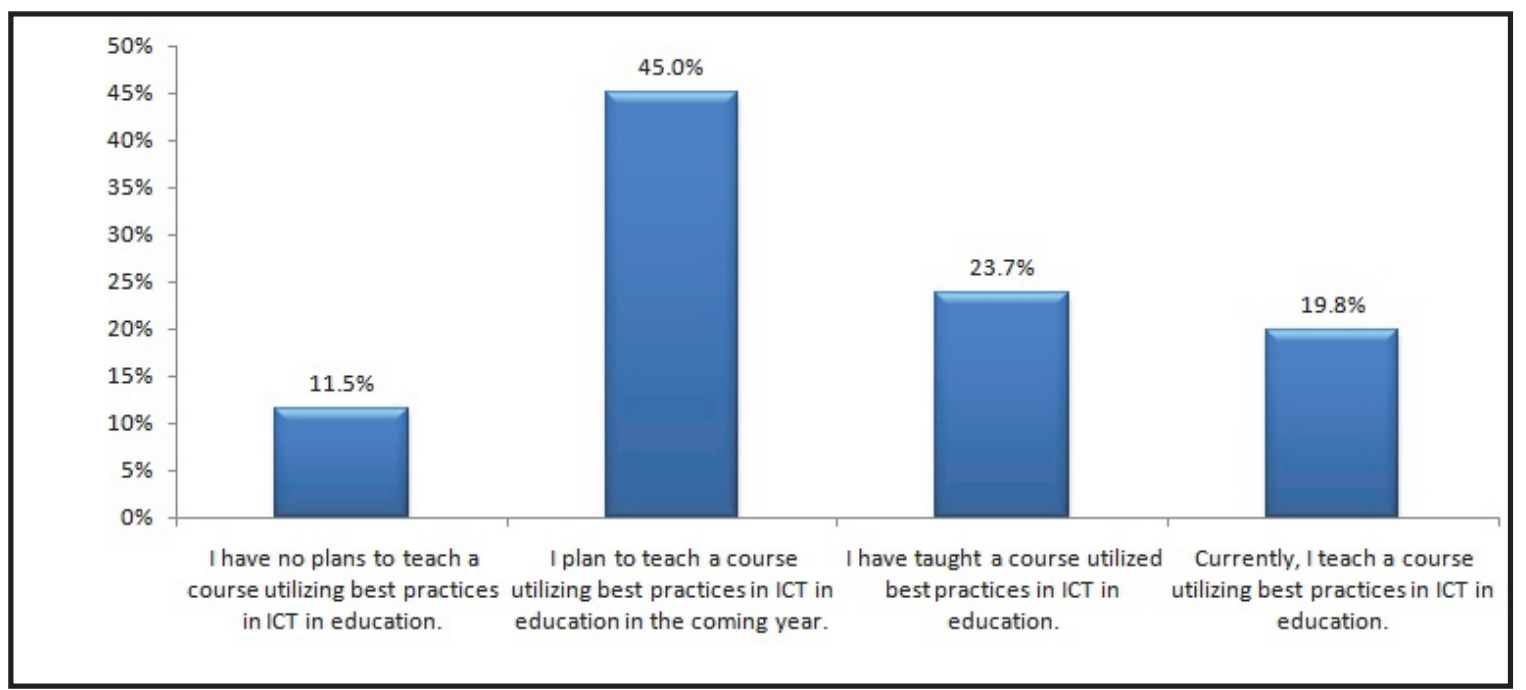

Figure 4. Faculty Members' Plans Regarding Using ICT Tools in Education (Percent)

As shown in Figure 4 above, the results indicated that a very large number of respondents (45.0\%) plan or have the intention to use ICT in education in the coming year. About (43.5\%) are currently teaching a course utilizing best practices in ICT in education or previously had taught a course utilized best practices in ICT in education.

The results revealed that 97 respondents (37.2\%) have not teach any course utilizing ICT; whereas 91 respondents (34.7\%) have taught 1-3 courses utilizing ICT; while 47 respondents $(17.9 \%)$ have taught $4-6$ courses; 11 respondents $(4.1 \%)$ have taught 7-10 courses utilizing ICT; and 16 respondents $(6.1 \%)$ have taught more than 10 courses.

Survey question 10 asked whether faculty members have attended a training session about ICT use. Eighty-one 
faculty members indicated that they have attended a training session about ICT use (30.9\%); while 181 faculty members indicated that they have not attended a training session regarding ICT use (69.1\%), as shown in Figure 5.

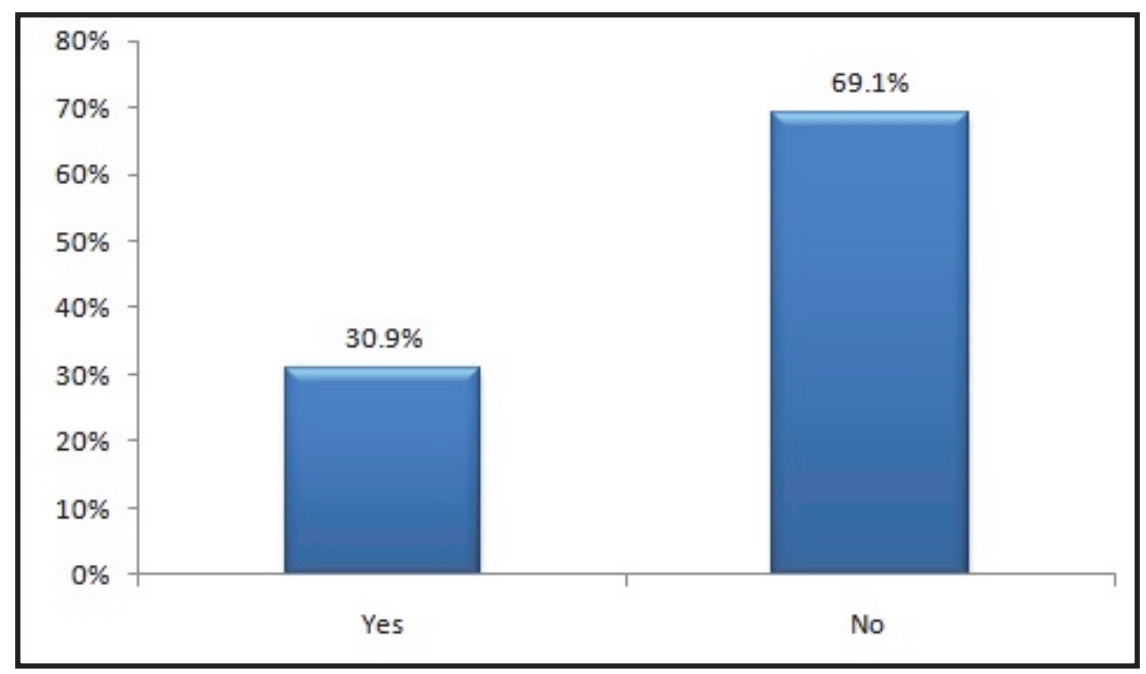

Figure 5. Attending a Training Session about ICT Use (Percent)

As shown in Figure 5 above, the results indicated that around two thirds of the respondents have not attended ICT training sessions; hence, those who did not attended ICT training sessions may had used other resources to learn ICT best practices.

In a question asked about the classification of the ICT users, ICT faculty users versus ICT faculty non-users; 165 faculty members (the majority) classified themselves as ICT faculty users (63\%), whereas 97 faculty members classified themselves as ICT faculty non-users (37\%) as shown in Figure 6.

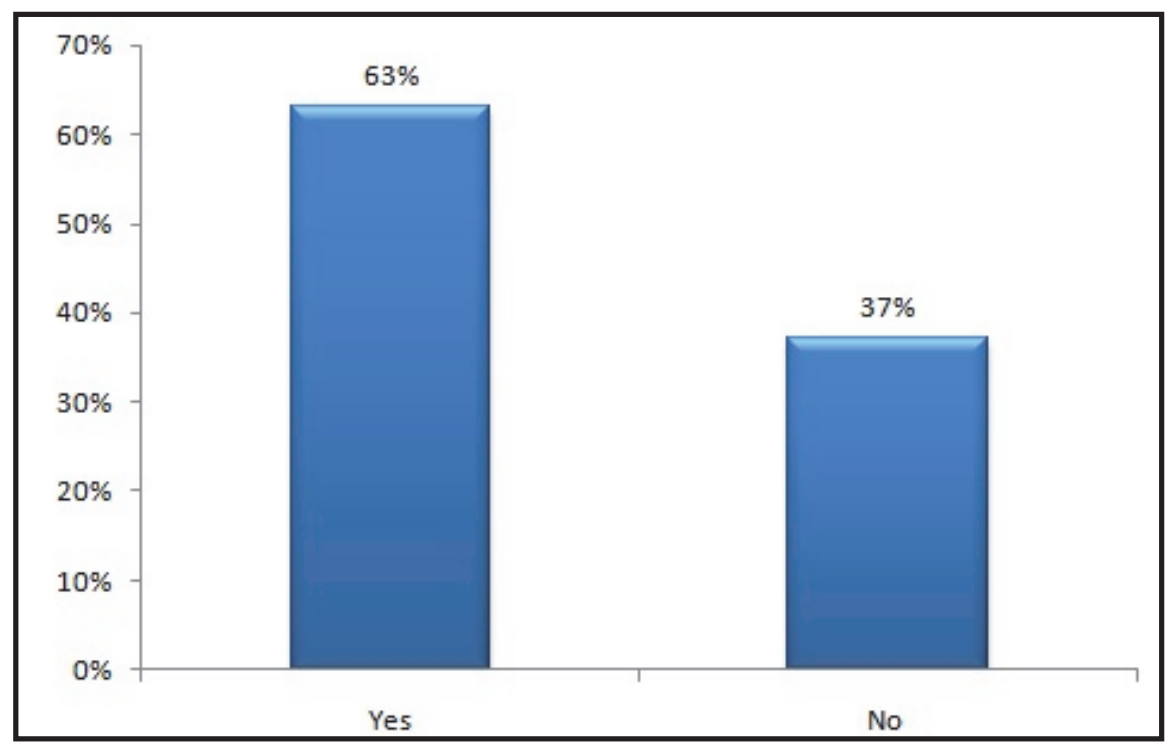

Figure 6. Faculty Users and Non-users of ICT Tools (Percent)

It is important to mention that questions (12-15) of the survey targeted the ICT non-user only; thus, there were merely 97 respondents who answered this question as a faculty member ICT non-user.

Survey question 12 , which was for ICT faculty non-users only $(\mathrm{N}=97)$, asked whether they would be interested in using or adopting ICT tools in their teaching practices in the future. This finding confirms that all of the ICT faculty non-users respondents (100\%), who answered "Yes" to this question, are interested in using ICT tools in the future. Question 13 of the survey, which was for ICT faculty non-users only, asked whether they would be willing to or 
be interested in teaching a course that utilizes ICT tools in the future. This result verifies that all of the ICT faculty non-users respondents $(100 \%)$, who answered "Yes" to this question, are willing to or interest in teaching a course that utilizes ICT tools in the future.

Question 14 of the survey, which was for ICT faculty non-users only, asking whether they would be interested in receiving training (in both pedagogy and technology) about the use of ICT tools in the future. This result validates that 92 respondents out of 97 (94.8\%) of the ICT faculty non-users are interested in receiving training (in both pedagogy and technology) about the use of ICT in the future; whereas, only 5 respondents (5.2\%) of the ICT faculty non-users are not interested in receiving training about the use of ICT in the future, as shown in Figure 7 below.

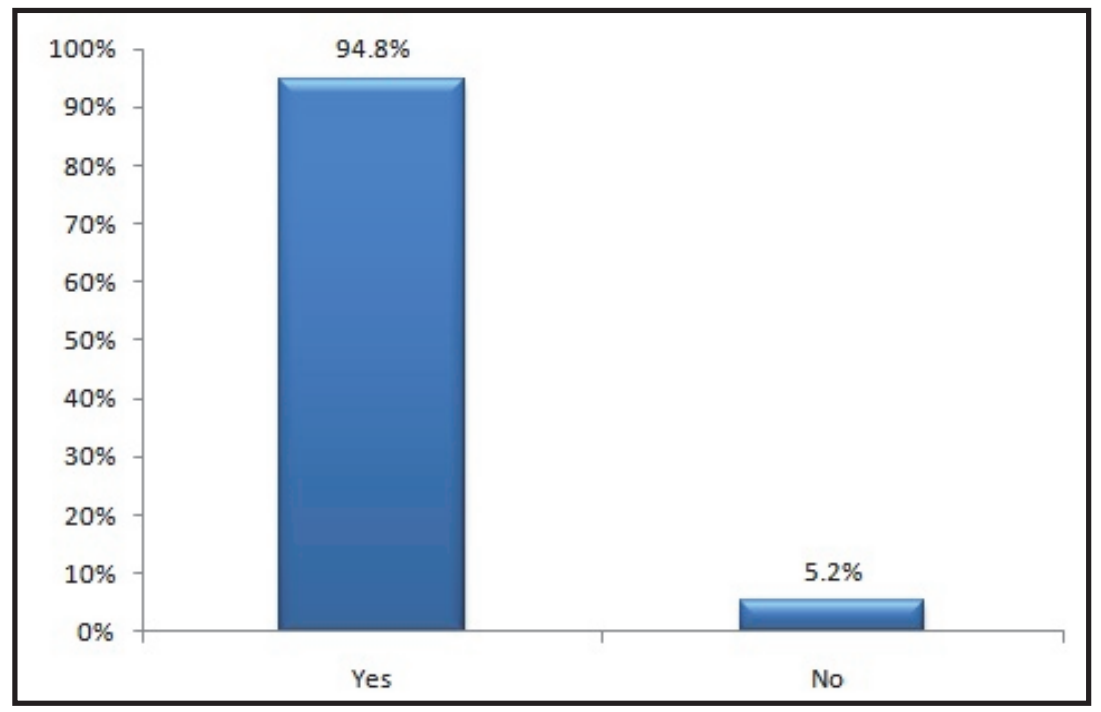

Figure 7. ICT Faculty Non-users' Interest in Receiving Training about the Use of ICT in the Future (Percent)

Figure 8 below corresponds to question 15 of the survey, which was for ICT faculty non-users only; asking what would the major deterrent to their decision to teach a course that utilizes ICT tools in the future. In this question of the survey, respondents addressed each statement using a five-point Likert-type response set: 1=Strongly Disagree, $2=$ Disagree, $3=$ Do Not Know (neither disagree nor agree), $4=$ Agree, $5=$ Strongly Agree. For the data analysis purposes, the interpretation of mean score (degree) as follows: (1-2.33) low, (2.34-3.67) moderate, (3.685) high.

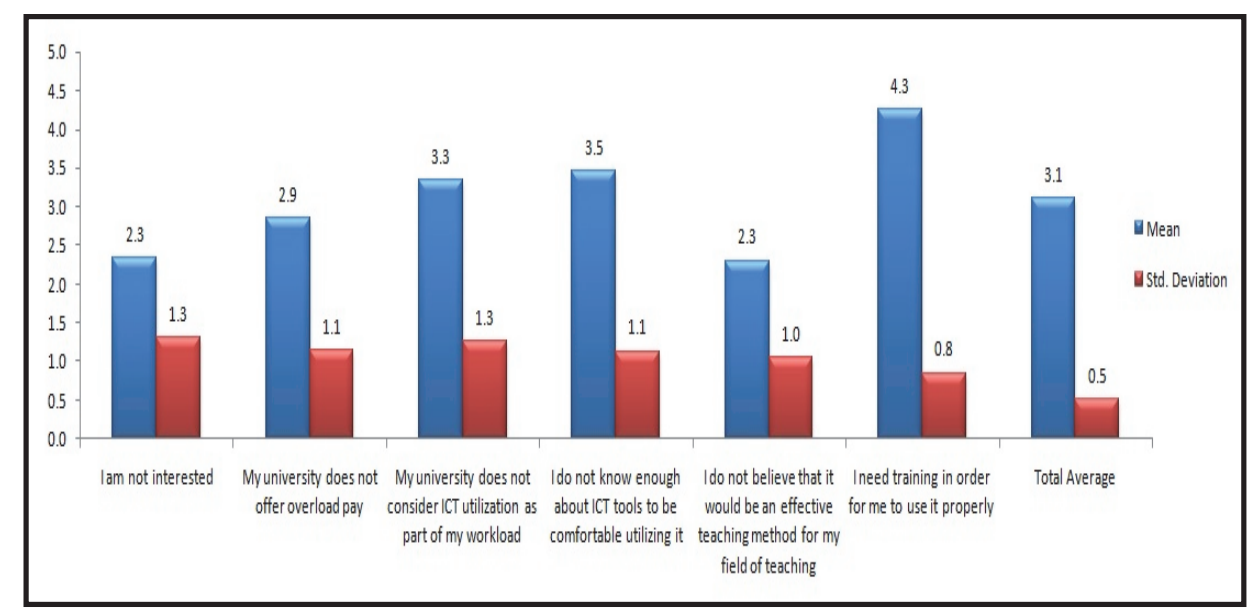

Figure 8. ICT Faculty Non-users' Major Deterrent/Obstacles to Teach a Course Utilizing ICT Tools in the Future 
As shown in Figure 8 above, the overall mean (total average) of these six statements is (3.1) with a moderate degree. This indicates that ICT faculty non-users rate those major deterrents to their teaching a course utilizing ICT tools in the future to a moderate level; which implies that it can be overcome these obstacles or barriers.

Also from the figure above, it can be concluded that statement one (I am not interested), and statement five (I do not believe that it would be an effective teaching method for my field of teaching) with the same mean (2.3) have low degrees. But statement two (My university does not offer overload pay), statement three (My university does not consider ICT utilization as part of my workload), and statement four (I do not know enough about ICT tools to be comfortable utilizing it) with means of $(2.9,3.3,3.5)$ respectively have moderate degrees. While statement six (I need training in order for me to use it properly) with mean of (4.3) has a high degree.

Referring to Figure 8 above, it can be concluded that the order of the major deterrent or obstacles, as perceived by ICT faculty non-users, ranking in descending order according to the mean is represented in Table 2.

Table 2. Major Deterrent/Obstacles, as Perceived by ICT Faculty Non-Users, Ranking in Descending Order According to the Mean

\begin{tabular}{cccl}
\hline Statement No. & Ranking & Mean & Degree \\
\hline 6 & 1 & 4.3 & High \\
4 & 2 & 3.5 & Moderate \\
3 & 3 & 3.3 & Moderate \\
2 & 4 & 2.9 & Moderate \\
1 & 5 & 2.3 & Low \\
5 & 5 & 2.3 & Low \\
Total Average & & $\mathbf{3 . 1}$ & Moderate \\
\hline
\end{tabular}

As mentioned earlier, it is important to point out that survey questions 16 through 23 were directed to all respondents of the study; that is, those who use ICT tools and who never have used ICT tools at these four Jordanian universities (ICT faculty users and non-users).

Nevertheless, most participants, ICT faculty users and non-users $(N=262)$, were generally positive in their perceptions of ICT at these Jordanian academic institutions (53.1\% of the respondents are supportive towards the use of ICT at a personal level). Figure 9 corresponds to question 16 of the survey which asked about how faculty members, overall, perceive the use of ICT tools.

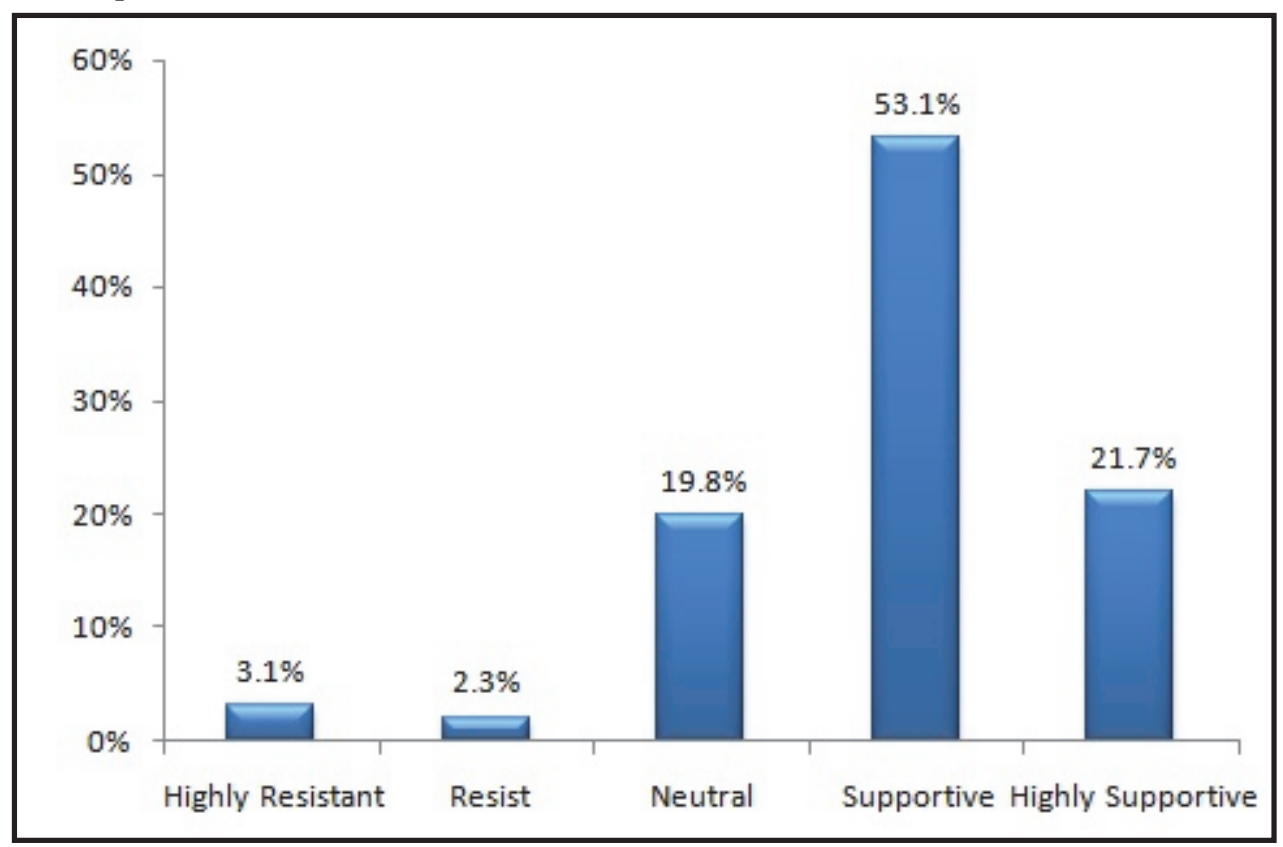

Figure 9. ICT ICT Faculty Users and Non-users' Perceptions of the Use of ICT (Percent) 
In question 17 of the survey, asking whether the nature of the courses faculty members are teaching influences their decision about whether or not to use ICT tools, 27 faculty members (10.3\%) indicated they (strongly agree) that the nature of the courses they are teaching influences their decision about whether or not to use ICT tools; 142 faculty members $(54.2 \%)$ indicated they (agree) that the nature of the courses they are teaching influences their decision about whether or not to use ICT tools; 27 faculty members (10.3\%) indicated they (do not know) that the nature of the courses they are teaching influences their decision about whether or not to use ICT tools; 55 faculty members $(21.0 \%)$ indicated they (disagree) that the nature of the courses they are teaching influences their decision about whether or not to use ICT tools; and 11 faculty members (4.2\%) indicated they (strongly disagree) that the nature of the courses they are teaching influences their decision about whether or not to use ICT tools as shown in Figure 10. Therefore, the results indicated that the majority of the respondents $(54.2 \%)$ believe that the nature of the subject is a key factor to decide to use ICT tools in teaching and learning process.

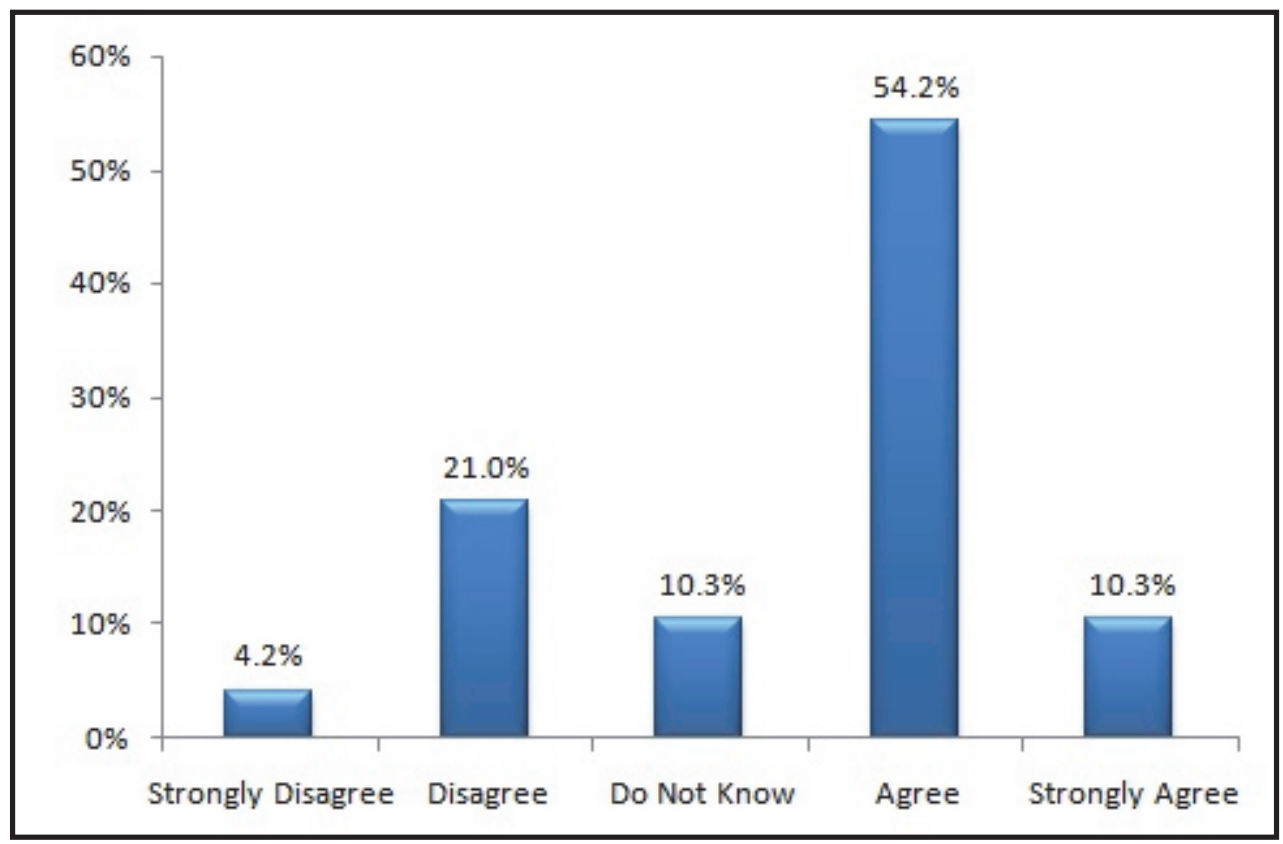

Figure 10. Does the Nature of the Courses that Faculty Members are Teaching Influence their Decision about whether or not to Use ICT Tools? (Percent)

Question 18 of the survey is an open-ended question; it asked about what would have an impact on expanding faculty members' use of ICT, or their intention to use ICT, in the near future?; (148) respondents did not answer this question, (4) respondents answered "I do not know", and (110) respondents provided an answer to this question of the survey. The major themes that emerging from the respondents who answered this question are as follows: the availability of infrastructure, resources, computers, speed internet, proper ICT tools, logistics by the institution, and technology; the availability of ICT Training Center; provide a proper training on the use of ICT tools; the availability of continuous technical support; the availability of time; develop students' skills; equip classes with interactive whiteboards; access to specialized facilities - more smart classrooms; improve the quality of the services offered by the Information Technology Center at the university in order to make the actual use of ICT; reduce the teaching load; reduce the number of students enrolled in the classes that utilizing ICT tools; the availability of Wifi, PCs, and Datashow Projectors in classrooms; and improve teaching methodologies.

Question 19 of the survey, which consisted of six statements, asked about what are or would be the major incentives for using ICT tools; specifically, they asked to rate the extent to which they agree with the provided statements about major incentives for utilizing ICT in education. ICT faculty users and non-users respondents addressed each statement using a five-point Likert-type response set: $1=$ Strongly Disagree, $2=$ Disagree, $3=$ Do Not Know (neither disagree nor agree), $4=$ Agree, $5=$ Strongly Agree. For the data analysis purposes, the interpretation of mean score as follows: (1-2.33) low, (2.34-3.67) moderate, (3.68-5) high.

As shown in Figure 11, the overall mean (total average) of these six statements is (3.7) with a high degree. This 
indicates that ICT faculty users and non-users rate those major incentives for utilizing ICT tools in education to a high level; which implies that these incentives can play a major role in enhancing the utilization level of ICT in the teaching and learning process.

Also from the figure below, it can be concluded that statement one (extra pay or overload assignment) with a mean (3.1), statement two (extra time) with a mean (3.6), and statement six (I was required to use it) with a mean (2.9) are having moderate degrees. While statement three (it sounds interesting), statement four (I think students would benefit), and statement five (I am interested in utilizing ICT in education) with means of $(4.0,4.2,4.3)$ respectively have high degrees.

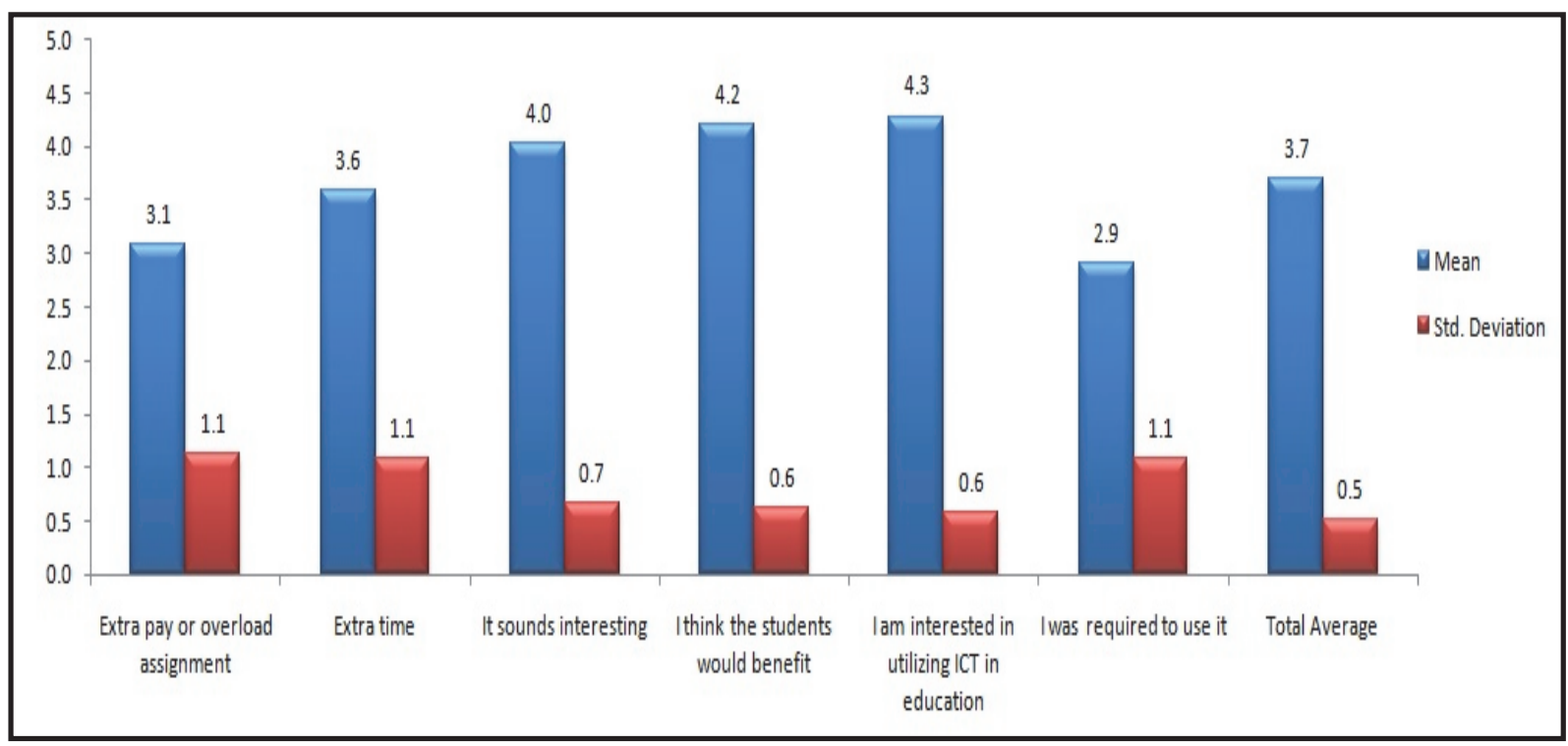

Figure 11. ICT Faculty Users and Non-users’ Major Incentives for Utilizing ICT in Education

Referring to Figure 11 above, it can be concluded that the order of the major incentives, as perceived by ICT faculty users and non-users, ranking in descending order according to the mean is represented in Table 3.

Table 3. Major Incentives, as Perceived by ICT Faculty Users and Non-Users, Ranking in Descending Order According to the Mean

\begin{tabular}{ccll}
\hline Statement No. & Ranking & Mean & Degree \\
\hline 5 & 1 & 4.3 & High \\
4 & 2 & 4.2 & High \\
3 & 3 & 4.0 & High \\
2 & 4 & 3.6 & Moderate \\
1 & 5 & 3.1 & Moderate \\
6 & 6 & 2.9 & Moderate \\
Total Average & & $\mathbf{3 . 7}$ & High \\
\hline
\end{tabular}

Question 20 of the survey is an open-ended question; it asked about what do faculty members consider as the main barriers for integrating ICT and technology in general in educational activities at their universities?; (118) respondents did not answer this question, (2) respondents answered "I do not know", and (142) respondents provided an answer to this question of the survey. The major barriers or obstacles for integrating ICT in education as perceived by the respondents, who answered this question, are as follows: lack of smart rooms and infrastructure; logistics and time; students' skills; no incentives; training availability on the use of ICT tools; the number of students enrolled; lack of training and time; lack of equipment, technical expertise and interest; lack of userfriendly software and Lack of internet security; teaching overload; the limited budget for using ICT; lack of 
facilities, laboratories, and equipment; limited recourses; the traditional methods of teaching; the detailed nature of the course; and no previous experience on using the ICT tools.

In question 21 of the survey, ICT faculty users and non-users were asked to rate the extent to which they agree with nine statements using a five-point Likert-type response set: $1=$ Strongly Disagree, $2=$ Disagree, $3=$ Do Not Know (neither disagree nor agree), $4=$ Agree, $5=$ Strongly Agree. For the data analysis purposes, the interpretation of mean score as follows: (1-2.33) low, (2.34-3.67) moderate, (3.68-5) high.

As shown in Figure 12, the overall mean (total average) of these nine statements is (3.7) with a high degree. Also from the figure below, it can be concluded that statement six (Traditional classroom-based courses and ICT based courses are given the same Recognition) with a mean (2.7), statement eight (ICT instruction is at least as effective as face-to-face instruction) with a mean (3.1), and statement nine (Teacher-student interaction is difficult when using ICT tools to deliver instruction) with a mean (3.0) are having moderate degrees. While statement one (Faculty members need more time available for implementing ICT) with a mean (3.9), statement two (ICT is positively related to the learning process) with a mean (4.0), statement three (ICT could effectively serve students with different backgrounds) with a mean (4.1), statement four (ICT could be a useful tool for supporting traditional methods of teaching) with a mean (4.0), statement five (ICT can be a more stimulating method of teaching than traditional instruction) with a mean (4.1), and statement seven (Lack of technical knowledge prevents the use of ICT tools) with a mean (4.1), are all having high degrees.

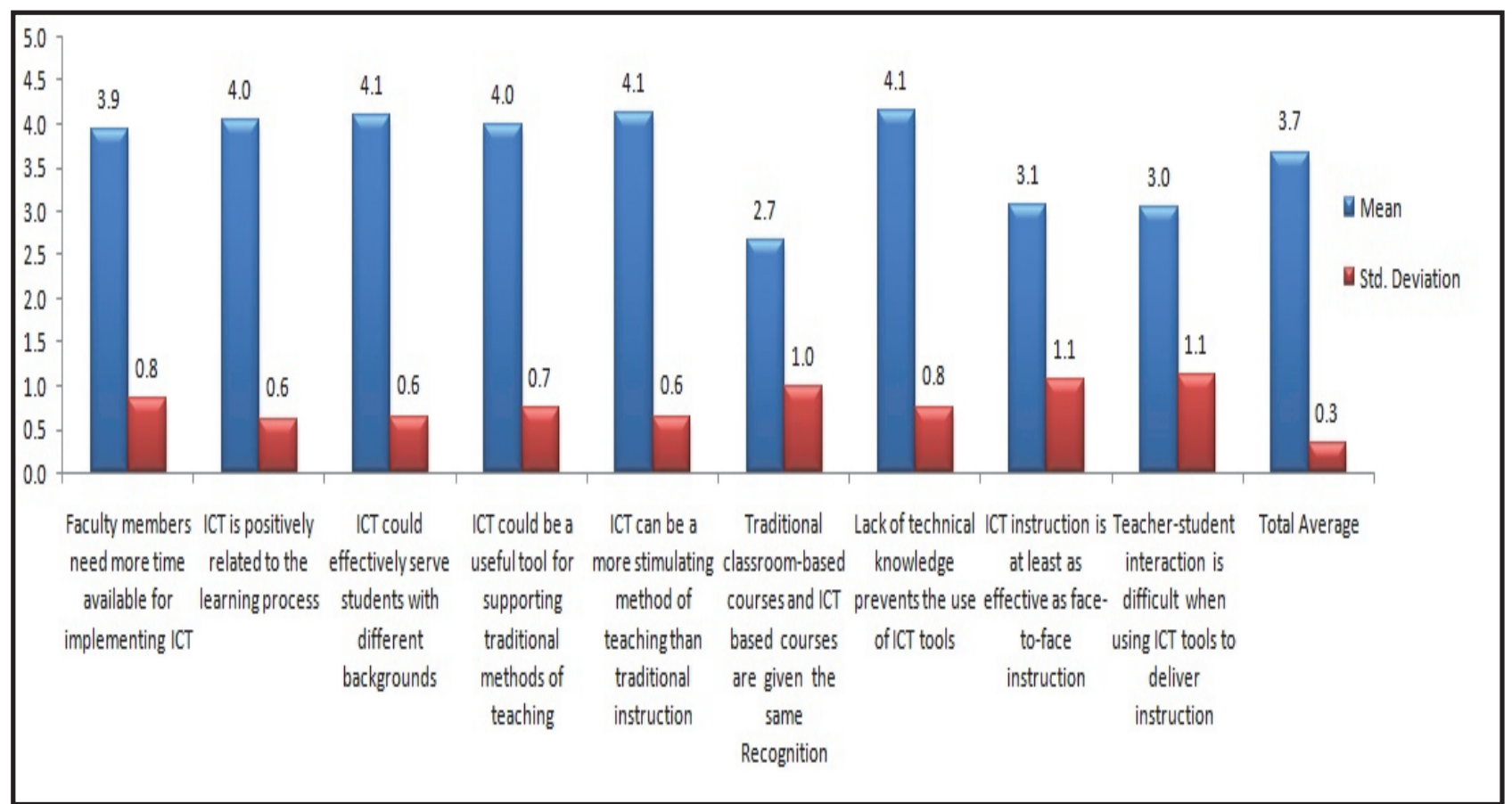

Figure 12. ICT Faculty Users and Non-users Rating the Extent to which They Agree with Nine Specific Statements

Referring to Figure 12 above, it can be concluded that the order of the comparison between ICT tools method of teaching and traditional/conventional teaching method, ranking in descending order according to the mean is represented in Table 4.

Table 4. Comparison between ICT Tools Method of Teaching and Traditional/Conventional Teaching Method, Ranking in Descending Order According to the Mean

\begin{tabular}{cccl}
\hline Statement No. & Ranking & Mean & Degree \\
\hline 7 & 1 & 4.1 & High \\
5 & 1 & 4.1 & High \\
3 & 1 & 4.1 & High
\end{tabular}




\begin{tabular}{cccl}
4 & 4 & 4.0 & High \\
2 & 4 & 4.0 & High \\
1 & 6 & 3.9 & High \\
8 & 7 & 3.1 & Moderate \\
9 & 8 & 3.0 & Moderate \\
6 & 9 & 2.7 & Moderate \\
Total Average & & $\mathbf{3 . 7}$ & High \\
\hline
\end{tabular}

Question 22 of the survey is an open-ended question; it asked about, what kind of teaching and learning activities can be done by using ICT that are not possible using other methods, from faculty members' point of view; (148) respondents did not answer this question, (10) respondents answered "I do not know", and (104) respondents provided an answer to this question of the survey. The major themes that emerging from the respondents, who answered this question, are as follows: many courses especially those which have some video and those which need weekly assignment and follow up; group discussions in large classes; communication after the school hours, Online Discussion, Problem Solving, and Critical Thinking; watching videos to support what is being taught in the classroom; simulation and animation; courses related to web-based learning; independent, self-paced learning; using forums for discussions and making comments to assignments; quizzes and homework; PowerPoint presentations, displaying videos from YouTube; and assignments, group dissociation for difficult topics, and short exams.

The last question of the survey (question 23) is an open-ended question; it asked the participants whether they want to make any additional comments they would like to add or anything else they would like to mention about the use of ICT; however, answering this question was optional; (148) faculty members provided an answer to this question of the survey. The followings are some of those comments as stated by the respondents: "I would like to see a Training Center for ICT at my university which can provide the help and support to the faculty members to adopt ICT in the courses which they are teaching. Also, I would like to see some smart class rooms". "ICT has a little influence on teaching". "I am concerned about the scarce resources at the disposal of my university and the impact of ICT on the fair evaluation of students' achievements". "I'm very much interested in using ICT to explore it and see the impact on my students and their feedback. After that I may consider using it for all my courses or to forget it at all". "Training for faculty to use this method is essential to make its use with confidence, and more time/course load for the preparation of the learning material taught". "The use of ICT is not supposed to be a replacement of the face-to-face meetings. There should be at least $25 \%$ of face-to-face meetings with students". "Infrastructural and handy technical support are very important if ICT "in the way I see it" to make a difference". "Next time, please write your survey in Arabic in order to make the question clear and understandable by all faculty members". And "Integrating ICT in teaching learning process is necessary".

\section{Discussion}

This study examined faculty members' perceptions towards the use of ICT in higher education institutions in Jordan, and the issues and concerns influencing their perceptions. Particularly, the overall aim of this study was to explore the major incentives and challenges/obstructions facing the implementation of ICT by faculty members in Jordanian universities. For the purpose of this study, two major research questions were investigated: (a) what are the main incentives for using ICT in higher education institutions in Jordan as perceived by faculty members?; and (b) what are the main obstacles for using ICT in higher education institutions in Jordan as perceived by faculty members? The discussion of the findings of these research questions are presented below.

In total there were 262 responses which were analyzed descriptively. According to the obtained data from the completed surveys, the key results were: (a) most respondents indicated that they were confident in their abilities in a lot of ICT related tasks; (b) overall the instructors' attitudes towards the use of ICT in the classroom were very positive, although there were some concerns that staff training in these technologies could be improved; and (c) despite the challenges that all instructors in the sample encountered when using ICT in their teaching (such as large classrooms, lack of time, and lack of technology tools), the encouragement of university administration was a critical factor in instructors' continuation of ICT use.

Also, data from the completed surveys revealed that the majority of the e-Learning non-user participants would be: (a) interested in using ICT in the future, (b) willing to or interested in teaching a course that utilizes ICT tools in the future, and (c) interested in receiving training about the use of ICT tools in the future. Furthermore, ICT non-user participants indicated that the most major deterrents to their teaching a course that utilizes ICT tools in 
the future are: they need training in order for them to use it properly, they do not know enough about ICT tools to be comfortable utilizing it, and their universities do not consider ICT utilization as part of their workload.

Overall, this study reviews and investigates factors that influence instructors' decisions to use ICT in their instruction. Thus, the purpose of this study is to identify the main factors affecting the attitudes of the faculty members towards the use of ICT in their teaching activities. It found that the major factors affecting instructors' use of ICT are: (a) Instructors' characteristics: (e.g. individual's educational level, age, gender, educational experience, experience with the ICT for educational purposes, and faculty rank) can influence the adoption of an innovation (Rogers, 2003). (b) Availability of vision and plan about the contribution of ICT to education: instructors need to know exactly how ICT is used as a teaching and learning tool; instructors must have opportunities to study, observe, reflect, and discuss their practice, including their use of ICT, in order to develop a sound pedagogy that incorporates technology (Schiller, 2003).

(c) Level of and accessibility to the ICT Infrastructure: using up-to-date hardware and software resources is a key feature to diffusion of technology (Gülbahar, 2007). (d) Availability of time, to experiment, reflect and interact: according to Mumtaz (2000), lack of time is a factor that hinders technology integration in schools and universities. (e) Available support to ICT-using instructor in the workplace: the lack of technical support reported as one of the major barriers that resulted in ICT being underutilized in the classes (Butler \& Sellbom, 2002). (f) Level and quality of training for instructors: professional development of instructors sits at the heart of any successful technology and education program (Baylor \& Ritchie, 2002).

(g) Attitude towards ICT: instructors' attitudes have been found to be major predictors of the use of new technologies in instructional settings (Almusalam, 2001). (h) Computer and technology competence: according to Pelgrum (2001), the success of educational innovations depends largely on the skills and knowledge of instructors. And (j) Instructor workload: many studies have revealed that the workloads of instructors influence their acceptance of technology in classrooms (Neyland, 2011).

In addition, data from the completed surveys revealed that the factors determining the continuous use of technology in teaching can be categorized as follows: (a) professional development factors which comprise of the instructors' perceived values of the professional development program, and the opportunity for continuous learning; (b) personal factors which comprises of instructor belief, knowledge and skills, time and engagement; (c) institutional factors comprising the accessibility to technology, support from the management, and environment; (d) technological factors which comprises ease of use and effectiveness, where ease of use refers to the convenience, adequacy, reliability and user friendly of the technology, whereas effectiveness refers to the likelihood of the long tangible benefits for the institution, improved learning and communication. These factors were confirmed by Kafyulilo, Fisser, and Voogt's (2016) study.

Based on the findings of both the close-ended and open-ended questions of the survey, enabling (incentives) and hindering (obstacles) factors affecting the continuation of technology use by the faculty members at Jordanian higher education institutions are summarized as follows:

1. Factors facilitating implementation of ICT: Instructors' positive perceptions towards the use of ICT in the classroom, ubiquitous use of technology as a motivating factor for ICT utilization, innovative culture among the recently graduated instructors, change management, well-equipped infrastructure, administrative support, prompt maintenance of digital and computerized devices, availability of technological tools, usefulness of ICT, ease of use, opportunity to improve the teaching process, greater course flexibility for students, personal motivation to use technology, overall job satisfaction, credit toward promotion and tenure, increase in salary, release time, recognitions and awards, grants for materials/expenses, requirement by department, professional prestige and status, and perceived benefits from using ICT by the instructors were also an important facilitating/motivational factor.

2. Factors hindering implementation of ICT: lack of presence of incentives for good practices, teaching overload, inadequate training, lack of time, lack of technical knowledge and ICT skills, the availability and cost of technologies, high cost of computer maintenance and upgrading, fear of computer and technology breakdown during teaching process, frequent breakdown of computer and other digital equipment, insufficient internet connectivity, high cost of hardware and software, resistance to organisational change, lack of specialised personnel in technology, financial support, and lack of motivation for the instructors in using ICT tools.

The increasing use of ICT in higher education has been explored largely in relation to instructor's attitude towards the use of ICT in the universities. However, the success of ICT in any learning institution including higher education institutions depends on the attitudes of instructors towards using ICT in their daily teaching practices. 
Therefore, this study aimed to investigate the critical factors that impact instructors' use of ICT in teaching and learning process at Jordanian universities. Hence, the analysis of the data of the questionnaire, overall, indicated that most participants (instructors) were generally positive in their perceptions of the use of ICT at these Jordanian academic institutions; they affirmed that ICT tools must be used to enhance the teaching and learning process.

In terms of the factors influencing the use of ICT, survey was conducted to investigate the factors affecting instructors' use of ICT; the results revealed that the critical factors affecting instructors' perceived satisfaction towards the use of ICT are instructor attitude towards ICT, perceived usefulness, and perceived ease of use. The results also showed what the academic institutions can do to improve instructors' satisfaction and further strengthen their ICT implementation.

On the one hand, an understanding of faculty members' perceptions on which motivational factors would encourage them to integrate ICT into their educational practice is important for the successful introduction of ICT in higher education. Incentives are important for enhancing individual performances and achievements. They are important for both individuals and organizations (Fisher, 2003; Abdul-Aziz, 2008). The integration of ICT into higher education has benefits for all stakeholders. In developing countries, there has been increasing interest in integrating ICT into higher education. This interest is driven by the availability and affordability of several types of digital technology in the hands of the university staff and students. University students are heavy users of popular ICT for personal and social purposes; however, the integration of ICT into higher education, and students' use of ICT for educational purposes, depends on faculty members' practices.

On the other hand, the results of the study identified several institutional and personal barriers to the use of ICT that have been referred to elsewhere; resistance to change fear of technology workload seems to be an additional barrier. However, several interesting subject differences have emerged. The faculty members participated in this study ranged from those who regularly used ICT to those, who did not use ICT to such a great extent (ICT faculty users versus ICT faculty non-users). In this regard, the attitudes of ICT faculty non-users towards ICT were positive related to their thinking that working with ICT would be enjoyable and stimulating, and their want to learn more about ICT tools.

Referring to ICT faculty users and non-users which mentioned in the previous paragraph, it was therefore recommended that peer support could be a beneficial route for improving the use of ICT in universities via a connectivist approach, with more experienced users being able to support those with less experience. However, when deploying ICT in the teaching and learning process, a close attention should be given to the connectivist approach; given that connectivism is a theory of learning in a digital age that emphasizes the role of social and cultural context in how and where learning occurs; learning does not simply happen within an individual, but within and across the networks.

In general, the participants in this study indicated that several motivational factors would encourage them to integrate ICT into their educational practice. The most significant factors were internal and personal ones related to the direct benefits of the ICT for enhancing their teaching practice, enhancing students' learning, and improving their job satisfaction. Material and moral incentives, as well as university support and encouragement, have a high influence on faculty members' use of ICT for educational purposes. The findings suggest that the faculty members could be motivated to use ICT in their educational practice if the university supported them to integrate ICT in ways that enhanced their teaching and benefited their students. In addition, faculty members could be motivated to use ICT in their educational practice by offering them time-related and financial incentives. The university could play an integral role in motivating faculty members to implement ICT in their educational practice by: requiring the use of ICT, encouraging the use of ICT, and providing "timely training and support" related to the use of ICT (Gasaymeh et al., 2017).

Faculty members' instructional practices are driven by their motivations. Therefore, it is important for institutions of higher education to understand what measures would encourage faculty members to integrate ICT in their educational practice. Based on the findings, the institutions of higher education should increase their faculty members' awareness and knowledge of the anticipated benefits of the use of ICT in their educational practice in term of enhancing their teaching practice and career and improving their students' learning. In order to enhance faculty members' awareness and knowledge of the anticipated benefits of the use of ICT, presentations, seminars, and regular meetings with faculty members who had experience with the use of ICT in education can be conducted (Guri-Rosenblit, 2009).

The institutions of higher education should encourage faculty members through establishing financial, moral, incentive system to promote faculty members' integration of ICT in their educational practice. Such system should include different types of incentives such as monetary, time related, job security related, working conditions related, 
and recognition incentives. The incentive system should include continuous process of identifying and meeting the motivational factors of faculty members. Institutions of higher education should continually support faculty members in their integration of ICT in their educational practice through requiring them to use ICT, encouraging them to use ICT, and providing "timely training and support" related to the use of ICT in their educational practice. Faculty members should be constantly encouraged and supported to make the integration of ICT part of their permanent educational practice. It is not enough to only encourage them to try to integrate ICT into their educational practice. The integration of ICT should be inherent in the higher education institutions' mission, vision, and philosophy. This is needed to motivate faculty members' integration of ICT into their educational practice (Lai, 2011).

In short, like all technology, ICT tools have their own advantages and disadvantages; however, the success of ICT utilization in higher education rests on the willingness of instructors to use such technology, the learners' cooperation and positive perceptions towards the use of such technology, and the academic institutional support provided to facilitate the desired implementation.

\section{Conclusions, Implications, and Recommendations for Future Research}

This section of the study presents the summary of the study findings, conclusions, research implications, recommendation of the research, limitations, and future research which contains suggestions of related studies that may be carried out in the future.

The integration of ICT in education is considered as an asset for encouraging technological growth. Its use not only changes the traditional ways of teaching, but also requires tutors to be more creative in adapting and customizing their own teaching materials and strategies for encouraging instructors to adapt this new form of learning. The success of ICT in any learning institution including the Jordanian higher education institutions depends on the attitudes of instructors towards using ICT in their daily teaching practices. For this purpose, it is essential to understand what factors may influence the usage of ICT among the instructors. In this study, incentives and obstacles factors have been explored in the higher education institutions in Jordan. Consequently, the general objective of this study was to investigate the factors influencing effective use of ICT in learning and teaching. Several factors determine the success or failure of use of ICT in teaching and learning.

In summary, Jordanian Universities need to adopt a rational use of resources by giving ICT the first priority; integrating new advanced technology means that universities need more training for both instructors and students, which involves extra time, effort and cost (Al-Shboul et al., 2017). Furthermore, Jordanian universities need to harness ICT tools to make the classroom experience more appealing to prospective students.

\subsection{Conclusions}

This study has contributed to the growing body of knowledge in the field of ICT diffusion in higher education, particularly in Jordan. Also, it has added to ICT diffusion research in general and the diffusion of innovation in developing countries in particular. The findings of the study are relevant to educational systems to evaluate the utilization of ICT, the innovation and its acceptance within university life. Consequently, the purpose of this study was to identify prevalent instructors' perceptions towards the use of ICT tools in higher education institutions in Jordan and to explore the main incentives and barriers that might motivate or prevent the effective use of ICT in four Jordanian universities, from faculty members' perspectives. The data were collected via a Web-based survey that was developed to explore incentives and barriers to integrating ICT in Jordanian higher education. The participant sample for this study consisted of faculty members who employed at four Jordanian universities during the Fall Semester of 2017/2018. The total numbers of participants who completed and returned the survey was 262.

Based on the findings/results of the study, it can be concluded that: (1) Most participants, ICT faculty users and non-users $(N=262)$, were generally positive in their perceptions of ICT at these Jordanian academic institutions. (2) Data from the completed surveys revealed that the majority of the ICT non-user participants ( $n=97)$ would be: (a) interested in using ICT in the future, (b) willing to or interested in teaching a course that utilizes ICT tools in the future, and (c) interested in receiving training about the use of ICT tools in the future. (3) Furthermore, ICT non-user participants indicated that the most major deterrents to their teaching a course that utilizes ICT tools in the future are: (a) they need training in order for them to use it properly, (b) they do not know enough about ICT tools to be comfortable utilizing it, and (c) their universities did not consider ICT utilization as part of their workload.

In conclusion, faculty members were generally positive in their perceptions of the use of ICT at higher education institutions in Jordan. However, the systematic review of the literature identified important issues which need to 
be in place for ICT to effectively take place. The barriers and potential solutions identified are useful for those designing ICT tools in any professional context. In the present study, the population sample that responded to the surveys came from four universities located in urban areas. Future research should collect a larger population sample including a broader range of respondents from both urban and rural areas.

Finally, in terms of the limitation of the study, it is suggested that the findings of this study can be further validated by using larger heterogeneous sample by involving an element of quantitative approach to be more able to generalize the findings and identify the major incentives and obstacles or barriers among the identified ones.

\subsection{Implications}

In the light of the results of this study, the researcher offers the following recommendations that might assist higher education decision makers and instructors in integrating ICT in higher education institutions in Jordan:

1. Jordanian Universities should develop strategies for evaluating the impact of ICT at different levels in the university, so that staff members are confident in assessing its influence on teaching and learning.

2. Jordanian Universities should be provided with adequate technical support to assist both instructors and students in using different ICT tools.

3. Jordanian Universities should consider convening an ICT steering committee, which could assist in managing the development of the ICT plan and in monitoring and reviewing its continuing implementation.

4. ICT adequate training must be provided to both ICT faculty users and non-users.

5. ICT technical support and maintenance must be provided.

6. The necessary technological infrastructure should be developed in the classrooms.

In summary, the systematic review of the literature identified important issues which need to be in place for ICT to effectively take place. The motivational factors, barriers and obstacles, as well as potential solutions identified are useful for those designing ICT tools in any professional context.

\subsection{Recommendations for Future Research}

Findings of the study offered recommendations that would be useful to ICT course instructors, administrators, and designers. Therefore, based on the findings of the study, the researcher recommends that:

1. University ICT policy makers investigate how instructors' existing competencies in the areas of enquiring and making use of ICT.

2. New learning and teaching approaches should utilize ICT and digital technologies that enhance students' skills in producing digital artefacts, critically questioning online materials, and using ethical digital practices.

3. There appears to be a large range between instructors who have strong digital skills, and instructors who are less confident with technology. Therefore, Universities need to cater both to instructors who require training in fundamental digital skills, and to those who would benefit from more advanced skills associated with production and participation with digital technologies.

4. Using ICT in education as scaffolding of new learning and teaching methods proved to be vital.

Last but not least, the study has some limitations related to the participants, methodology, and the ICT it examined. The results from this study suggest several areas for future:

1. In the present study, the population sample that responded to the surveys came from four universities located in urban area in Jordan; this limits the generalizability of the findings. Hence, future research should collect a larger population sample including a broader range of respondents from both urban and rural areas.

2. Future research into the role of the Open Educational Resources (OER) within students' learning requires greater clarification, as there are currently questions regarding whether the ICT tools and resources they provide are optimized for students' digital engagement. Spaces for learning outside of the classroom are increasingly being recognized as influential in students' learning due to the increased mobility provided by ICT and digital technologies (Wood \& Warwick, 2018), which need to be recognized and encouraged through university courses' curriculum and pedagogy.

3. This study used a quantitative approach in which self-reported data was collected using a questionnaire; future research should involve triangulation technique in order to validate the collected data. In other 
words, conduct a follow-up study with a selected sample of the original respondents using a qualitative data collection method to verify the findings of this study.

4. Conduct a similar study at different academic institutions (other Jordanian universities) to examine the identified issues related to instructors' perceptions towards the use of ICT.

5. Conduct further research on the best strategies for effective integration of ICT in educational practices at Jordanian higher education institutions.

6. Conduct a study to investigate the incentives and obstacles/barriers towards the use of ICT tools in higher education in Jordan from the perspective of the decision makers at the Jordanian universities administrations.

In summary, this study attempted to focus on faculty members' perceptions of the motivational and obstacles factors related to the utilization of ICT in higher education in Jordan. The findings of this study can have implications for future professional development programs that aim to develop ICT integration knowledge and skills. First, the professional development factor was important for the instructors' continuous use of ICT in teaching, because it initiated the development of ICT and technology integration knowledge and skills. Second, conditions for a long term impact of the professional development program depends on the instructors' ICT integration knowledge and skills, accessibility to ICT and the ease of use of the available ICT tools. Third, support form university administration is essential for faculty members' continuous use of ICT in teaching.

\section{Co-Funding}

This research study was co-funded by the Erasmus + Programme of the European Union, Erasmus + Programme METHODS Project number: 561940-EPP-1-2015-1-JO-EPPKA2-CBHE-JP, project title: Modernization of Teaching Methodologies in Higher Education: EU Experience for Jordan and Palestinian Territory (METHODS).

\section{Disclaimer}

This research project has been co-funded with support from the European Commission. This publication reflects the views only of the author, and the Commission cannot be held responsible for any use which may be made of the information contained therein.

\section{Acknowledgments}

The author is grateful to Prof. Ahmed Al-Salaymeh, the project General Coordinator-The University of Jordan and his assistant Lina Al-Marashdeh for their collaboration in facilitating conducting this study; also the author would like to thank all faculty members at these four Jordanian universities (UJ. JUST, HU, ZUJ) who participated in this research.

\section{References}

Abbad, M., Morris, D., \& de Nahlik, C. (2009). Looking under the Bonnet: Factors Affecting Student Adoption of E-Learning Systems in Jordan. International Review of Research in Open and Distance Learning, 10(2), 125. https://doi.org/10.19173/irrodl.v10i2.596

Abdul-Aziz, A. (2008). Distinguished Management of the Human Resources, Borders' Distinction. Al-Mansoura: Modern Bookshop.

Abu-Qudais, M., Al-Adhaileh, M., \& Al-Omari, A. (2010). Senior Faculty Members' Attitudes in Jordanian Universities towards Using Information and Communication Technology. International Arab Journal of eTechnology, 1(4), 135-141.

Agbo, I. (2015). Factors Influencing the Use of Information and Communication Technology (ICT) in Teaching and Learning Computer Studies in Ohaukwu Local Government Area of Ebonyi State-Nigeria. Journal of Education and Practice, 6(7), 71-87.

Al-Adwan, A., \& Smedley, J. (2012). Implementing e-Learning in the Jordanian Higher Education System: Factors Affecting Impact. International Journal of Education and Development Using Information and Communication Technology, 8(1), 121-135.

Al-Adwan, A., Al-Adwan, A., \& Smedley, J. (2013). Exploring Students' Acceptance of e-Learning Using Technology Acceptance Model in Jordanian Universities. International Journal of Education and Development using Information and Communication Technology, 9(2), 4-18.

Alassaf, H. (2014). Effective Strategies on Using ICT for Teaching and Learning Undergraduate Level at Jordanian Universities. Journal of Education and Practice, 5(3), 81-89. 
Albugami, S., \& Ahmed, V. (2015). Success Factors for ICT Implementation in Saudi Secondary Schools: From the Perspective of ICT Directors, Head Teachers, Teachers and Students. International Journal of Education and Development using Information and Communication Technology, 11(1), 36-54.

Alenezi, A. (2015). Influences of the Mandated Presence of ICT in Saudi Arabia Secondary Schools. International Journal of Information and Education Technology, 5(8), 638-644. https://doi.org/10.7763/IJIET.2015.V5.583

Aljaberi, N. (2015). The Competence of Teachers Embedded in the Classroom and Child Education Programs in Jordan, and It's Compatibility with the Required Competence of Teacher in the Age of Information Technology. American Journal of Educational Research, 3(7), 832-843.

Aljaraideh, Y., \& Shdooh, W. (2014). Factors Effecting the Usage of ICT by the Teaching Members at Jerash University. Canadian Social Science, 10(6), 222-226.

Al-Khasawneh, M. (2012). Adoption of Information and Communication Technology in Teaching and Learning Environment in Jordanian Higher Education Institutions (Unpublished doctoral dissertation). Universiti Utara Malaysia, Kedah, Malaysia.

Alkhawaldeh , N. (2010). Barriers to Utilizing ICT for Educational Purposes in Jordan (Unpublished master's thesis). Örebro University, Örebro, Sweden.

Alkhawaldeh, N., \& Menchaca, M. (2014). Barriers to Utilizing ICT in Education in Jordan. International Journal on E-Learning, 13(2), 127-155.

Almarabeh, T., Mohammad, H., Yousef, R., \& Majdalawi, Y. (2014). The University of Jordan e-Learning Platform: State, Students' Acceptance and Challenges. Journal of Software Engineering and Applications, 7(12), 9991007. https://doi.org/10.4236/jsea.2014.712087

Almarabeh, T. (2014). Students' Perceptions of e-Learning at the University of Jordan. International Journal of Emerging Technologies in Learning (iJET), 9(3), 31-35. https://doi.org/10.3991/ijet.v9i3.3347

Al-Mobaideen, H. (2009). ICT Diffusion in Jordanian Universities. Proceedings of the European and Mediterranean Conference on Information Systems, 2009, 1-21.

Al-Mofarreh, Y. (2016). Implementation of ICT Policy in Secondary Schools in Saudi Arabia (Unpublished doctoral dissertation). University of Wollongong, Wollongong, Australia.

Almusalam, S. (2001). Factors Related to the Use of Computer Technologies for Professional Tasks by Business and Administration Teachers at Saudi Technical Colleges (Unpublished doctoral dissertation). Ohio State University, Ohio, USA.

Al-Obisat, F., Alrawashdeh, H., Altarawneh, H., \& Altarawneh, M. (2013). Factors Affecting the Adoption of ELearning: Jordanian Universities Case Study. Computer Engineering and Intelligent Systems, 4(3), 32-40.

Al-Shboul, M., Rababah, O., Al-Saideh, M., Betawi, I., \& Jabbar, S. (2013). A Vision to Improve E-Learning at the University of Jordan. World Applied Sciences Journal, 21(6), 902-914.

Al-Shboul, M. (2013). The Level of E-Learning Integration at the University of Jordan: Challenges and Opportunities. International Education Studies, 6(4), 93-113. https://doi.org/10.5539/ies.v6n4p93

Al-Shboul, M. (2014). Faculty Members' Perceptions of E-Learning at The University of Jordan. International Journal of Instructional Technology and Distance Learning, 11(10), 3-44.

Al-Shboul, M., Al-Saideh, M., \& Al-Labadi, N. (2017). Learners' Perspectives of Using ICT in Higher Education Institutions in Jordan. International Journal of Instructional Technology and Distance Learning, 14(3), 2785.

Al-Shboul, M. (2017). Factors Affecting Instructors' Use of e-Learning at The University of Jordan. Proceedings of the $8^{\text {th }}$ International Conference on eLearning, 2017, 65-71.

Alshmrany, S., \& Wilkinson, B. (2014). Evaluating ICT Use in Saudi Arabian Secondary Schools. Proceedings of International Conference on Advanced Information and Communication Technology for Education, 2014, 7075. https://doi.org/10.2991/icaicte-14.2014.16

Alshmrany, S., \& Wilkinson, B. (2017). Factors Influencing the Adoption of ICT by Teachers in Primary Schools in Saudi Arabia. International Journal of Advanced Computer Science and Applications, 8(12), 143-156. https://doi.org/10.14569/IJACSA.2017.081218

Al-Zoubi, A., Kahhaleh, B., Hasan, O., \& Kharouf, H. (2007) Future Potential of ICT Implementation in University Education in Jordan. Proceedings of the 10th International Conference of Interactive Computer Aided 
Learning, 2007, 1-9.

Alzubi, K., \& Omar, M. (2015). Factors Influencing the Effectiveness of E-Learning System (EduWave) in the Educational Process. Journal of Information Engineering and Applications, 5(7), 1-13.

Ameen, N., Willis, R., \& Abdullah, M. (2017). The Use of e-Learning by Students in Iraqi Universities: Potential and Challenges. Proceedings of 8th International Visible Conference on Educational Studies \& Applied Linguistics, 2017, 369-381.

Aslan, A., \& Zhu, C. (2018). Starting Teachers' Integration of ICT into Their Teaching Practices in the Lower Secondary Schools in Turkey. Educational Sciences: Theory \& Practice, 18(1), 23-45. https://doi.org/10.12738/estp.2018.1.0431

Baylor, A., \& Ritchie, D. (2002). What Factors Facilitate Teacher Skill, Teacher Morale, and Perceived Student Learning in Technology Using Classrooms?. Computers \& Education, 39, 395-414. https://doi.org/10.1016/S0360-1315(02)00075-1

BECTA (2003). What the Research Says about Using ICT in Maths. British Educational Communications and Technology Agency. Retrieved from http://39lu337z5111zjr1ilntpio4-wpengine.netdna-ssl.com/wpcontent/uploads/2016/04/wtrs_17_maths.pdf

Bingimlas, K. (2009). Barriers to the Successful Integration of ICT in Teaching and Learning Environments: A Review of the Literature. Eurasia Journal of Mathematics, Science and Technology Education, 5(3), 235-245. https://doi.org/10.12973/ejmste/75275

Bryman, A. (2012). Social Research Methods. New York: Oxford University Press.

Bryman, A., \& Bell, E. (2015). Business Research Methods (4th ed.). New York: Oxford University Press Inc.

Butler, D., \& Sellbom, M. (2002). Barriers to Adopting Technology for Teaching and Learning. Educase Quarterly, 25(2), 22-28.

Chigona, A., \& Chigona, W. (2010). An Investigation of Factors Affecting the Use of ICT for Teaching in the Western Cape Schools. Proceedings of the 18th European Conference on Information Systems, 2010, 1-12.

Cox, M., Preston, C., \& Cox, K. (1999). What Factors Support or Prevent Teachers from Using ICT in their Classrooms? Proceedings of the British Educational Research Association Annual Conference, 1999, 1-8.

Daniels, J. (2002). Information and Communication Technology in Education-A Curriculum for Schools and Programme for Teacher Development. Paris: UNESCO publications.

Elshaikhi, F. (2015). Integrating Information Technology in Libyan Higher Education (Unpublished doctoral dissertation). University of Kansas, Kansas, USA.

Field, A. (2013). Discovering Statistics Using SPSS (4th ed.). London: SAGE.

Fisher, J. (2003). How to Make an Incentives and Rewards System? Cairo: Dar Al-Farouq for Publishing.

Gasaymeh, A., AlJa'afreh, I., Al-Dmour, A., \& Abu-Alrub, M. (2016). Higher Education Students' Preferences for Applying the Principles of Constructivism in Learning Programming Languages with the Use of ICTs. Journal of Studies in Education, 6(3), 168-187. https://doi.org/10.5296/jse.v6i3.9780

Gasaymeh, A., Al-hasanat, H., Kraishan, O., \& Abutayeh, K. (2017). Motivational Factors Affecting the Integration of Information and Communication Technology (ICT) in Education by Faculty Members: A Developing Country Perspective. International Journal of Education, 9(3), 168-182. https://doi.org/10.5296/ije.v9i3.11667

Ghavifekr, S., Kunjappan, T., Ramasamy, L., \& Anthony, A. (2016). Teaching and Learning with ICT Tools: Issues and Challenges from Teachers' Perceptions. Malaysian Online Journal of Educational Technology, 4(2), 3857.

Grainger, R. \& Tolhurst, D. (2005). Organizational Factors Affecting Teachers'Use and Perception of Information \& Communications Technology. Sydney: Australian Computer Society.

Gülbahar, Y. (2007). Technology Planning: A Roadmap to Successful Technology Integration in Schools. Journal of Computers \& Education, 49(4), 943-956. https://doi.org/10.1016/j.compedu.2005.12.002

Guri-Rosenblit, S. (2009). Digital Technologies in Higher Education: Sweeping Expectations and Actual Effects. New York: Nova Science. 
Hew, K., \& Brush, T. (2007). Integrating Technology into K-12 Teaching and Learning: Current Knowledge Gaps and Recommendations for Future Research. Educational Technology Research and Development, 55(3), 223252. https://doi.org/10.1007/s11423-006-9022-5

Higgins, S. (2003). Does ICT Improve Learning and Teaching in Schools? Nottingham: British Educational Research Association.

Kafyulilo, A., Fisser, P., \& Voogt, J. (2016). Factors Affecting Teachers' Continuation of Technology Use in Teaching. Education and Information Technologies, 21(6), 1535-1554. https://doi.org/10.1007/s10639-0159398-0

Karimi, G. (2012). Factors Affecting the Use of Information and Communication Technology in Teaching and Learning in Secondary Schools in Kangema- Murang 'a County (Unpublished master's thesis). Kenyatta University, Nairobi, Kenya.

Keiyoro, P. (2010). Factors Influencing the Effective Use of ICT in Teaching and Learning Science Curriculum in Kenyan Secondary Schools: The Case of Cyber and Nepad e-Schools (Unpublished doctoral dissertation). University of Nairobi, Nairobi, Kenya.

Kennah, M. (2016). The Use of ICT in the Teaching and Learning Process in Secondary Schools: A Case Study of Two Cameroonian schools (Unpublished master's thesis). University of Jyväskylä, Jyväskylän yliopisto, Finland.

Khasawneh, M., \& Ibrahim, H. (2012). A Model for Adoption of ICT in Jordanian Higher Education Institutions: An Empirical Study. Journal of e-Learning \& Higher Education, 2012(1), 1-10. https://doi.org/10.5171/2012.877178

Khasawneh, M. (2015). Factors Influence e-Learning Utilization in Jordanian Universities-Academic Staff Perspectives. Procedia-Social and Behavioral Sciences, 210, 170-180. https://doi.org/10.1016/j.sbspro.2015.11.356

Kozma R.B. (2008) Comparative Analysis of Policies for ICT in Education. In: Voogt J., Knezek G. (Eds), International Handbook of Information Technology in Primary and Secondary Education (Vol 20, pp. 10831096). Boston, MA: Springer. https://doi.org/10.1007/978-0-387-73315-9_68

Lai, K. (2011). Digital Technology and the Culture of Teaching and Learning in Higher Education. Australasian Journal of Educational Technology, 27(8), 1263-1275. https://doi.org/10.14742/ajet.892

Law, N., Lee, M., Chan, A., \& Yuen, A. (2008). Factors Influencing the Impact of ICT use on Students' Learning. Proceedings of the $8^{\text {th }}$ International Rangeland Congress, 2008, 1-17.

Lawrence, J., \& Tar, O. (2018). Factors that Influence Teachers' Adoption and Integration of ICT in Teaching/Learning Process. Educational Media International, 55(1), 79-105. https://doi.org/10.1080/09523987.2018.1439712

Lawrence, J. (2018). Factors Influencing Teachers' Integration of ICT in Teaching and Learning. International Journal of Adult Vocational Education and Technology, 9(2), 48-63. https://doi.org/10.4018/IJAVET.2018040104

Li, S., Yamaguchi, S., \& Takada, J. (2018). Understanding Factors Affecting Primary School Teachers' Use of ICT for Student-Centered Education in Mongolia. International Journal of Education and Development Using ICT. 14(1), 103-117.

Margaryan, A., Littlejohn, A., \& Vojt, G. (2011). Are Digital Natives a Myth or Reality? University Students' Use

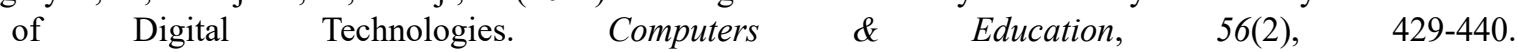
https://doi.org/10.1016/j.compedu.2010.09.004

Mellar, H., Kambouri, M., Logan, K., Betts, S., Nance, B., \& Moriarty, V. (2007). Effective Teaching and Learning: Using ICT. Retrieved from http://dera.ioe.ac.uk/22302/2/doc_3348.pdf

Mirzajani, H., Mahmud, R., Ayub, A., \& Luan, W. (2015). A Review of Research Literature on Obstacles that Prevent Use of ICT in Pre-Service Teachers' Educational Courses. International Journal of Education \& Literacy Studies, 3(2), 25-31.

Mishra, P., \& Koehler, M. (2006). Technological Pedagogical Content Knowledge: A Framework for Integrating Technology in Teachers' Knowledge. Teachers College Record, 108(6): 1017-1054. https://doi.org/10.1111/j.1467-9620.2006.00684.x 
Mofleh, S., \& Wanous, M. (2008). Developing Countries and ICT Initiatives: Lessons Learnt from Jordan's Experience. The Electronic Journal on Information Systems in Developing Countries, 34(5), 1-17. https://doi.org/10.1002/j.1681-4835.2008.tb00236.x

Mulhim, E. (2014). The Barriers to the Use of ICT in Teaching in Saudi Arabia: A Review of Literature. Universal Journal of Educational Research, 2(6), 487-493.

Mumtaz, S. (2000). Factors Affecting Teachers' Use of Information and Communications Technology: A Review of the Literature. Journal of Information Technology for Teacher Education, 9(3), 319-342. https://doi.org/10.1080/14759390000200096

Neyland, E. (2011). Integrating Online Learning in NSW Secondary Schools: Three Schools Perspectives on ICT Adoption. Australia Journal of Educational Technology, 27(1), 152-173. https://doi.org/10.14742/ajet.989

Nikolopoulou, K., \& Gialamas, V. (2016). Barriers to ICT Use in High Schools: Greek Teachers' Perceptions. Journal of Computers in Education, 3(1), 59-75. https://doi.org/10.1007/s40692-015-0052-z

Njuguna, G. (2013). Factors Influencing the Use of e-Learning in Public Universities in Kenya (Unpublished master's thesis). University of Nairobi, Nairobi, Kenya.

Noor-Ul-Amin, S. (2013). An Effective Use of ICT for Education and Learning by Drawing on Worlwide Knowledge, Research and Experience: ICT as a Change Agent for Education (A Literature Review). Retrieved from https://www.nyu.edu/classes/keefer/waoe/amins.pdf

Osman, N. (2014). The Acceptance and Use of Information and Communication Technologies by Staff Members in Khartoum State's Universities (Sudan) (Unpublished doctoral dissertation). Dresden University of Technology, Dresden, Germany.

Pelgrum, W. (2001). Obstacles to the Integration of ICT in Education: Result from Worldwide Educational Assessment. Computers and Education, 37, 163-178. https://doi.org/10.1016/S0360-1315(01)00045-8

Player-Koro, C. (2012) Factors Influencing Teachers' Use of ICT in Education, Education Inquiry, 3(1), 93-108. https://doi.org/10.3402/edui.v3i1.22015

Prasad, C., Lalitha, P., \& Srikar, P. (2015). Barriers to the Use of Information and Communication Technology (ICT) in Secondary Schools: Teacher's Perspective. Journal of Management Research, 7(2), 190-208. https://doi.org/10.5296/jmr.v7i2.6935

Qablan, A., Abuloum, A., \& Abu Al-Ruz, J. (2009). Effective Integration of ICT in Jordanian Schools: An Analysis of Pedagogical and Contextual Impediments in the Science Classroom. Journal of Science Education and Technology, 18(3), 291-300. https://doi.org/10.1007/s10956-009-9151-9

Qablan, B. (2015). Status of e-Learning Usage as Perceived by Jadara University Students-Jordan. Journal of Studies in Education, 5(2), 266-279. https://doi.org/10.5296/jse.v5i2.5581

Rockwell, S., Schauer, J., Fritz, S., \& Marx, D. (1999). Incentives and Obstacles Influencing Higher Education Faculty and Administrators to Teach Via Distance. Online Journal of Distance Learning Administration, 2(4), $1-10$.

Rogers, D. L. (2000). A Paradigm Shift: Technology Integration for Higher Education in the New Millennium. Educational Technology Review, 1(13), 19-33.

Rogers, E. M. (2003). Diffusions of Innovations (5th ed.). New York: Free Press.

Sabaliauskas, T., \& Pukelis, P. (2004). Barriers to Integration of Information and Communication Technologies into the Teaching and Learning Process. Proceedings of the European Conference on Educational Research, 2004, 1-8.

Saleh, S., \& Burgess, L. (2009). Factors Impacting the Adoption and Use of ICT in the Malaysian SME Sector. Proceedings of the $11^{\text {th }}$ International Business Research Conference, 2009, 1-24.

Sanchez, J., \& Salinas, A. (2008). ICT and Learning in Chilean Schools: Lessons Learned. Computers and Education, 51(4), 1621-1633. https://doi.org/10.1016/j.compedu.2008.04.001

Schiller, J. (2003). Working with ICT Perceptions of Australian Principals. Journal of Educational Administration, 41(2), 171-185. https://doi.org/10.1108/09578230310464675

Shaw, D. (2010). Bridging Sifferences: Saudi Arabian Students Reflect on their Educational Experiences and Share Success Strategies (Unpublished doctoral dissertation). Oregon State University, Oregon, USA. 
Tedla, B. (2012). Understanding the Importance, Impacts and Barriers of ICT on Teaching and Learning in East African Countries. International Journal for e-Learning Security, 2(3/4), 199-207. https://doi.org/10.20533/ijels.2046.4568.2012.0025

Tezci, E. (2009). Teachers' Effect on ICT Use in Education: The Turkey Sample. Procedia-Social and Behavioral Sciences, 1(1), 1285-1294. https://doi.org/10.1016/j.sbspro.2009.01.228

UNESCO Report (2009). Rector of Moscow Institute of Open Education and Jordan's Ministry of Information and Communications Technology to receive 2009 UNESCO King Hamad Bin Isa Al-Khalifa Prize. Retrieved from $\mathrm{http}: / /$ www.unesco.org/new/en/moscow/about-this-office/singleview/news/rector_of_moscow_institute_of_open_education_and_jordans/

White, G. (2008). ICT Trends in Education. Retrieved from http://citeseerx.ist.psu.edu/viewdoc/download?doi=10.1.1.465.8208\&rep=rep1\&type=pdf

Williams, P. (2015). Lessons from the Future: ICT Scenarios and the Education of Teachers. Journal of Education for Teaching, 31(4), 319-339. https://doi.org/10.1080/02607470500280209

Wood, P., \& Warwick, P. (2018). Exploring Complex Learning Spaces. Journal of Learning and Teaching in Higher Education, 1(1), 59-81. https://doi.org/10.29311/jlthe.v1i1.2591

Wozney, L., Venkatesh, V., \& Abrami, P. (2006). Implementing computer technologies: Teachers' perceptions and practices. Journal of Technology and Teacher Education, 14(1), 173-207.

Yalin, H., Karadeniz, S., \& Sahin, S. (2007). Barriers to Information and Communication Technologies Integration into Elementary Schools in Turkey. Journal of Applied Sciences, 7(24), 4036-4039. https://doi.org/10.3923/jas.2007.4036.4039

Yusuf, M. (2005). Information and Communication Education: Analyzing the Nigerian National Policy for Information Technology. International Education Journal, 6(3), 316-321.

Zureikat, K. (2014). The Effect of Information and Communications Technologies (ICT) in the Jordanian Universities. Information and Knowledge Management, 4(12), 122-132.

\section{Appendix}

Baseline Study - Faculty Members' Questionnaire

Dear Faculty Member,

You were selected as a possible participant in this study. Your participation is really important because your answers will help lead to a better understanding of faculty's attitudes toward the use of Information and Communication Technology (ICT) in Higher Education, including both those who currently do use and those who do not; also, your answers to the questionnaire will present information that will be useful to a project titled "Modernization of Teaching Methodologies in Higher Education: EU Experience for Jordan and Palestinian Territory (METHODS)" funded by Erasmus+ Programme. The survey will take approximately 15 minutes to complete. If you decide to participate in this study, please follow the link below to complete the survey. If you do not wish to participate, simply discard the questionnaire. Completing and submitting the questionnaire constitutes your consent to participate.

The survey is located on the Web at https://esurv.org/online-survey.php?surveyID=LBMKKK_c598c8a

Please be aware that you will need to complete the survey at your earliest convenience. Participation in this study is entirely voluntary; your willingness or unwillingness to participate will not affect your relationship with your university. However, there are no foreseeable risks in your participation in the study. If you decide to participate, you are free to withdraw and discontinue participation at any time without penalty and without loss of benefits to which you are otherwise entitled. If you withdraw from the study before data collection is completed, your data will be destroyed and dropped from the study.

Responses will be completely anonymous; your name will not appear anywhere on the survey. All of the information you provide will be kept confidential; only summaries of responses will be reported. Your survey response cannot be linked to you or information about you in any way. Once again, we would like to assure you that all information you provide will remain confidential. Please take a moment to answer the questions. This is an opportunity to help us to get essential information to ensure a successful implementation of the project; also we hope that you will answer the survey questions thoughtfully and thoroughly. 
Thank you in advance for your participation, assistance, and valuable input.

Sincerely,

METHODS Team

Erasmus + Programme Project Number: 561940-EPP-1-2015-1-JO-EPPKA2-CBHE-JP

Demographic Category (1-11)

1. What is the name of your University?

$\square$ The University of Jordan (UJ)

$\square$ Jordan University of Science and Technology (JUST)

$\square$ The Hashemite University (HU)

Al-Zaytoonah University of Jordan (ZUJ)

2. What is your age?

$\square$ Less than 30 years old

3. What is your current faculty rank?

$\square$ Lecturer $\square$ Assistant Professor

4. Including the current year, how many years of teaching experience do you have? year(s)

5. If you use ICT in teaching, how many years have you used ICT in instruction? year(s)

6. In what faculty do you teach?

$\square$ Health Faculties $\square$ Scientific Faculties Humanities Faculties $\square$ Other

7. What type of ICT delivery tools are you currently using or previously have used?

$\square$ Blackboard

$\square$ Webboard

$\square$ WebCT

$\square$ Moodle

$\square$ Self-created Webpage

$\square$ Mobile Learning (Twitter/Facebook/WhatsApp)

$\square$ Others (please specify)

8. As a current faculty member, which statement of the following applies to you (you can select more than one):

$\square$ I have no plans to teach a course utilizing best practices in ICT in education.

$\square$ I plan to teach a course utilizing best practices in ICT in education in the coming year.

$\square$ I have taught a course utilized best practices in ICT in education.

$\square$ Currently, I teach a course utilizing best practices in ICT in education.

9. How many courses, regardless of the area of subject, have you taught utilizing ICT?

10. Have you attended ICT training sessions?

$\square$ Yes

$\square$ No

11. For the purpose of this study, the term, ICT user, refers to a faculty member who is currently using or previously has used ICT tools. Whereas, the term, ICT non-user, refers to a faculty member who never has used ICT tools. Based on these two definitions, do you consider yourself ICT user?

$\square$ Yes $\quad \square$ No

- If the answer of question (11) above is "Yes", please skip questions (12 - 15)

12. As a faculty non-user of ICT would you be interested in using or adopting ICT in the future? 
$\square$ Yes $\quad \square$ No

13. As a faculty non-user of ICT, would you be willing to or interested in teaching a course that utilizes ICT tools in the future?

$\square$ Yes $\quad \square$ No

14. As a faculty non-user of ICT, would you be interested in receiving training (in both pedagogy and technology) about the use of ICT in the future?

$\square$ Yes $\quad \square$ No

15. As a faculty non-user, rate the extent to which you agree with the following statements about major deterrents to your teaching a course utilizing ICT tools in the future?

\begin{tabular}{|c|c|c|c|c|}
\hline & Strongly & & Do Not & Strongly \\
\hline Statements & Disagree & Disagree & Know Agree & Agree \\
\hline
\end{tabular}

o I am not interested

o My university does not offer overload pay

o My university does not consider ICT utilization as part of my workload

o I do not know enough about ICT tools to be comfortable utilizing it

$\begin{array}{lllll}1 & 2 & 3 & 4 & 5\end{array}$

$\begin{array}{lllll}1 & 2 & 3 & 4 & 5 \\ 1 & 2 & 3 & 4 & 5 \\ 1 & 2 & 3 & 4 & 5 \\ 1 & 2 & 3 & 4 & 5 \\ 1 & 2 & 3 & 4 & 5\end{array}$

16. Overall, how do you perceive the use of ICT personally?
$\square$ Highly Resistant
$\square$ Resist
$\square$ Neutral
Supportive
Highly Supportive

17. I believe that the nature of the courses (subject matter or content) that I am teaching influence my decision about whether or not to use ICT tools?

$\square$ Strongly Disagree $\quad \square$ Disagree $\quad \square$ Do Not Know $\quad \square$ Agree $\quad \square$ Strongly Agree

18. What would have an impact on expanding your use of ICT, or your intention to use ICT, in the near future?

19. As a faculty member user, rate the extent to which you agree with the following statements about major incentives for utilizing ICT in education; and as a faculty non-user, rate the extent to which you agree with the following statements about major incentives for you to utilize ICT in education in the future?

\begin{tabular}{lccccc}
\hline & Strongly & \multicolumn{2}{c}{ Do Not } & Strongly \\
Statements & Disagree & Disagree & Know Agree & Agree \\
ay or overload assignment & 1 & 2 & 3 & 4 & 5 \\
ime & 1 & 2 & 3 & 4 & 5 \\
ds interesting & 1 & 2 & 3 & 4 & 5 \\
the students would benefit & 1 & 2 & 3 & 4 & 5 \\
terested in utilizing ICT in education & 1 & 2 & 3 & 4 & 5 \\
& 1 & 2 & 3 & 4 & 5
\end{tabular}

20. What do you consider as the main barriers for integrating ICT and technology in general in educational activities at your university? Please specify 
21. Rate the extent to which you agree with the following statements:

\section{Statements}

o Faculty members need more time available for implementing ICT

o ICT is positively related to the learning process

o ICT could effectively serve students with different backgrounds

o ICT could be a useful tool for supporting traditional methods of teaching

o ICT can be a more stimulating method of teaching than traditional instruction

o Traditional classroom-based courses and ICT based courses are given the same Recognition

o Lack of technical knowledge prevents the use of ICT 1 tools

o ICT instruction is at least as effective as face-to-face instruction

o Teacher-student interaction is difficult when using ICT tools to deliver instruction

Disagree

1

\section{Strongly \\ Do Not \\ Strongly}

Disagree

Know

Agree Agree

2

3

4

5

$\begin{array}{lllll}1 & 2 & 3 & 4 & 5\end{array}$

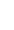

$\begin{array}{lllll}1 & 2 & 3 & 4 & 5\end{array}$

$\begin{array}{lllll}1 & 2 & 3 & 4 & 5\end{array}$

$\begin{array}{lllll}1 & 2 & 3 & 4 & 5\end{array}$

2

34

5

5

5

5

